\title{
Characterisation of spatial variability in water quality in the Great Barrier Reef catchments using multivariate statistical analysis
}

\author{
S. Liu ${ }^{\mathrm{a}, *}$, D. Ryu ${ }^{\mathrm{a}}$, J.A. Webb ${ }^{\mathrm{a}}$, A. Lintern ${ }^{\mathrm{a}}$,, D. Waters ${ }^{\mathrm{c}}$, Danlu Guo ${ }^{\mathrm{a}}$, A.W. Western ${ }^{\mathrm{a}}$ \\ a Department of Infrastructure Engineering, The University of Melbourne, Parkville, VIC 3010, Australia \\ ${ }^{\mathrm{b}}$ Department of Civil Engineering, Monash University, VIC 3800, Australia \\ c Queensland Department of Natural Resources, Mines and Energy, Toowoomba, QLD 4350, Australia
}

\section{A R T I C L E I N F O}

Keywords:

Water quality

Great Barrier Reef catchments

Multivariate analysis

Catchment characteristics

Land use

\begin{abstract}
A B S T R A C T
Water quality monitoring is important to assess changes in inland and coastal water quality. The focus of this study was to improve understanding of the spatial component of spatial-temporal water quality dynamics, particularly the spatial variability in water quality and the association between this spatial variability and catchment characteristics. A dataset of nine water quality constituents collected from 32 monitoring sites over a 11-year period (2006-2016), across the Great Barrier Reef catchments (Queensland, Australia), were evaluated by multivariate techniques. Two clusters were identified, which were strongly associated with catchment characteristics. A two-step Principal Component Analysis/Factor Analysis revealed four groupings of constituents with similar spatial pattern and allowed the key catchment characteristics affecting water quality to be determined. These findings provide a more nuanced view of spatial variations in water quality compared with previous understanding and an improved basis for water quality management to protect nearshore marine ecosystem.
\end{abstract}

\section{Introduction}

Degradation of water quality is a global issue (Schwarzenbach et al., 2010). Human activities, such as agriculture and urbanisation, are major causes of water quality degradation (Zia et al., 2013). For example, Bricker et al. (2014) showed that the excess nutrient discharge to coastal waters in the Chesapeake Bay region of the USA over the past 200 years was linked to increased anthrophonic pressures, including discharge from sewage treatment plants, and runoff from urban and agricultural land uses.

In-stream surface water quality is important for the health of inland and coastal waters (De'ath et al., 2012; Harris, 2001; Packett et al., 2009). For instance, discharge of sediments and nutrients to marine ecosystems from inland catchments poses a threat to near-shore tropical coral reefs globally (Aronson et al., 2014; Ginsburg and Shinn, 1995). Coral reefs maintain not only environments with rich biodiversity, but they also provide economic benefits from tourism, fishing and aquaculture (Chabanet et al., 1997; Connell, 1978). The ecosystem in the Great Barrier Reef (GBR), Australia, has been deteriorating during recent decades (DeVantier et al., 2006). It is estimated that the GBR- wide coral cover has decreased by $50 \%$ since 1985 , and the coral cover on inshore reefs has declined by 34\% since 2005 (Brodie et al., 2013). De Valck and Rolfe (2018) estimated that failure to maintain water quality in GBR could result in substantial losses of local economic benefits associated with tourism.

While there are many reasons for the reduction in coral cover in the Great Barrier Reef, poor quality of the water discharging into the reef from the inland catchments is thought to be one major cause (Brodie et al., 2012; Hunter and Walton, 2008; McKergow et al., 2005). Suspended sediments (often derived from soil erosion) have resulted in a reduction in the light essential for organisms in marine ecosystems, including seagrass and coral. Sediments and organic rich flocculent masses can also smother marine organisms when particles settle out (Brodie et al., 2013; Haynes, 2001). Nutrients, especially nitrogen and phosphorus, have been closely linked to the observed decline in coral cover through these two mechanisms. Excessive nutrients have facilitated outbreaks of the crown-of-thorns starfish, a major coral predator (Brodie et al., 2005; Fabricius et al., 2010), and they have also been implicated in coral bleaching (Hoegh-Guldberg et al., 2007; Wooldridge and Done, 2009).

\footnotetext{
* Corresponding author.

Email address: shucil@student.unimelb.edu.au (S. Liu)
} 
To protect aquatic environmental health and values in both rivers and bays, it is recognised that an improved water quality management strategy is essential (Lynam et al., 2010; Santhi et al., 2006; Sidle et al., 2006). This requires a sound understanding of the underlying reasons for water quality degradation in these rivers. However, constituent concentrations are highly variable in space and time due to hydrological variability (Allan et al., 1997), physical and bio-chemical processes (Ayers and Westcot, 1985; Letterman, 1999; Melching and Flores, 1999) and hydrological transport (Hrachowitz et al., 2016). Therefore, it is important to understand the spatial and temporal controls of water quality (Zhou et al., 2007b).

Previous studies of the Great Barrier Reef catchments using the water quality record have been conducted which either estimated the constituent loads (Kroon et al., 2012; Wallace et al., 2016), or focus on small scale or individual catchments land use effect of pollutant exports (Hunter and Walton, 2008; Packett et al., 2009; Stephen Lewis et al., 2014). Other efforts to understand variations in water quality in the Great Barrier Reef catchment have centred on modelling (Carroll et al., 2012; McCloskey et al., 2011; Waters et al., 2013). Through these earlier studies, a conceptual understanding of the role of different catchment characteristics in controlling differences in water quality between catchment is emerging. In addition, given the importance of catchment water quality to the Great Barrier Reef marine ecosystem, a detailed water quality monitoring system has been implemented by the Queensland Department of Science, Information and Innovation (DSITI). The detailed catchment scale monitoring data resulting from that monitoring system has not been systematically compared with catchment characteristics to date.

Most studies addressing the association between water quality and catchment characteristics have focused on temperate catchments in Asia, America and Europe (Ding et al., 2016; Donohue et al., 2006; Lowrance et al., 1997; Renard et al., 1997; Rice et al., 2015; Suif et al., 2016; Vrebos et al., 2017; Wu et al., 2015). Much less research has been undertaken in tropical catchments, like the Great Barrier Reef catchments. The key anthropogenic influences leading to water quality degradation in the Great Barrier Reef catchments have previously been studied at local scales. These include the relationship between sediment and particulate nutrients and erosion processes, and between non-point source dissolved nutrient and pesticide pollution from agricultural activities (Davis et al., 2016, 2017; Kroon et al., 2012; Kroon et al., 2016; Kuhnert et al., 2012; McKergow et al., 2005). These working hypotheses need continual testing as more detailed data emerge.

Multivariate statistical techniques can be used to explore the underlying patterns and potentially the processes affecting multi-site, multi-parameter water quality time-series data. Studies have used multivariate techniques such as cluster analysis and principal component analysis to interpret complex environmental monitoring data (Ouyang et al., 2014; Singh et al., 2004), identify sources of spatial variability in water quality (Mitra et al., 2017; Yang et al., 2010; Zhou et al., 2007a) and assessing monitoring networks (Shrestha and Kazama, 2007; Zhang et al., 2009). For instance, Li et al. (2011) used cluster analysis to detect the key groups of sites with similar water quality responses along the Middle Route of the South to North Water Transfer Project, China. They identified three groups of sites, reflecting the water quality responses of the sites, reflecting the main drivers of water quality: natural, agricultural and industrial sources.

It is well recognised that spatial and temporal dynamics in water quality are influenced by a wide range of natural and anthropogenic factors (Alberto et al., 2001; Kuhnert et al., 2012; Pratt and Chang, 2012; Singh et al., 2004). In this paper, serving as the initial part of a large study that aims to understand both spatial and temporal responses in water quality, we concentrate on the key catchment characteristics affecting spatial variability in stream water quality. We analysed water quality monitoring data from thirty-two sites using multivariate statistical analysis, over an 11-year period (2006-2016), using the time-averaged constituents concentrations (discussed in Section 2.4, Data preparation). The aim of the present study was to characterise spatial water quality variation, and to evaluate the relationships between spatial variations in water quality and catchment characteristics (e.g., land use, catchment geological, topographic and climatic conditions). The findings from the Great Barrier Reef catchments contribute to the growing understanding and knowledge of the key factors affecting spatial variability in water quality. In particular, this study addresses the following questions. (i) How strong is the spatial pattern in the concentration of water quality constituents across the Great Barrier Reef catchments? (ii) Are there groups of constituents with similar spatial behaviour? (iii) To what degree is the pattern in water quality associated with the catchment characteristics and what are they? (iv) What is the relative importance of anthropogenic controls and natural controls on water quality, and how these controls inform the management practices to improve water quality? The evaluation of the current conceptual understanding of catchment controls on water quality will further our understanding of spatial controls (e.g., catchment land use and hydrodynamic conditions) of water quality in the Great Barrier Reef catchments, so we can better manage our riverine water quality.

\section{Materials and methods}

\subsection{Study area}

The Great Barrier Reef catchments are located in north-eastern Australia and encompass northern to southern coastal and inland Queensland. In total, the catchments have an area of $432,134 \mathrm{~km}^{2}$ and are divided into six Natural Resource Management (NRM) regions (Carroll et al., 2012; Waters et al., 2014) (Fig. 1). According to the Köppen-Geiger climate classification, the Great Barrier Reef catchment climates range from semi-arid tropical or thru warm oceanic to wet tropical (Fig. 2a) (Peel et al., 2007), with annual rainfall ranging from around $500 \mathrm{~mm}$ in semi-arid tropical regions to $8000 \mathrm{~mm}$ in parts of the wet tropics where there are strong orographic effects near the coast (Fig. 2c) (Petheram et al., 2008). In most areas, rainfall declines from the coast to inland catchments. Generally, for inland semi-arid tropical regions, the precipitation predominantly occurs during the wet season, from November to April (Davis et al., 2016), while for the costal wet tropics, rainfall is more evenly distributed across the year. Major rainfall events are associated with tropical cyclones occurring in northern part of Great Barrier Reef catchments (Furnas, 2003; Hutchings et al., 2005). Most of the catchments drain eastwards into the Coral Sea from the Great Dividing Range, and they vary widely in topography from rugged mountains to flat river valleys and coastal plains (Fig. 2b).

Land use includes large areas of conservation lands, often covered with tropical forests; and a variety of agricultural uses including pastoral grazing, extensive rain-fed cropping and intensive rain-fed and irrigated sugar cane. Fig. 2d shows that the predominant land uses within the Great Barrier Reef catchments include grazing ( $~ 75 \%)$, nature conservation $(\sim 13 \%)$, cropping (e.g., horticulture, $\sim 3 \%$ ) and sugar cane ( 1\%) (Queensland Government, 2017). Denser human settlements and intensive agricultural landscapes have been developed in the coastal catchments. A detailed description of each site in terms of climate and monitored area are provided in Supplementary materials (Table S-1).

\subsection{Water quality data collection}

We used data from 32 water quality monitoring sites (Fig. 1) across six natural resource management regions. Water quality monitoring data was provided from the Paddock to Reef Integrated Monitoring, 


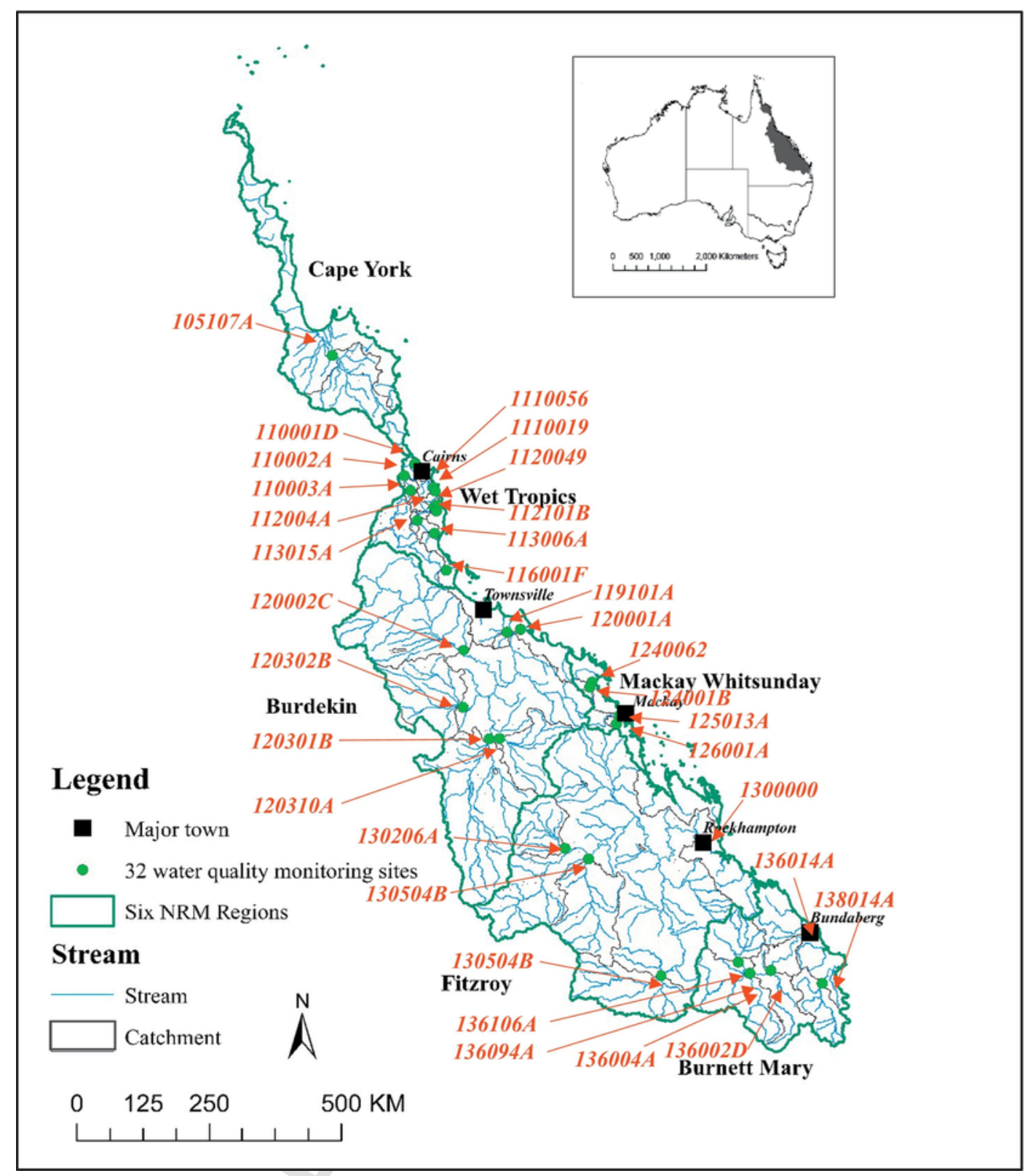

Fig. 1. Locations of 32 water quality monitoring sites in the Great Barrier Reef catchments.

Modelling and Reporting Program (Turner et al., 2012). The number of samples and temporal coverage vary by site (Table S-2), with largest number of samples were taken at 113006A Tully River at Euramo (e.g., 1441 samples of TSS) between 2006 and 2016 (e.g., 266 samples in 2006, Table S-3). Both intensive event-based water quality sampling during high flow events and monthly sampling during low or base flow (ambient) conditions were undertaken. During event periods, it was common that multiple samples to be collected on any given day. We analysed data collected from 2006 to 2016 . Samples were taken by either manual grab sampling or automatic samplers. The nine constituents considered in this study are summarised in Table 1.

\subsection{Catchment characteristics data collection}

Previous studies have indicated that catchment characteristics including land use (Li et al., 2009; Uriarte et al., 2011), geology and soil properties (Chang, 2008; Rothwell et al., 2010; Sangani et al., 2015), and climate and hydrology (Kleinman et al., 2004; Smith et al., 1997) can influence the spatial variability in water quality responses (Granger et al., 2010; Lintern et al., 2018). As such land use, topographic, climatic and soil characteristics were calculated from geospatial data sets for use as explanatory variables in the analysis of spatial variability in water quality responses.

The catchments of the 32 monitoring sites and their corresponding areas were delineated using the Australian Bureau of Meteorology Geofabric dataset (Bureau of Meteorology, 2011). The characteristics of these 32 catchments varied significantly (Tables S-2 and S-5). For instance, catchment areas ranged from 228 to $139,159 \mathrm{~km}^{2}$. Table 2 describes the different types and sources of the catchment characteristics used in this study.

Land use information from the Queensland Land Use Mapping Program (QLUMP) (Queensland Government, 2017) was used to separate land use into eight categories (Fig. S-1). A description of how different land uses were aggregated is included in Supplementary materials (Table S-5). 


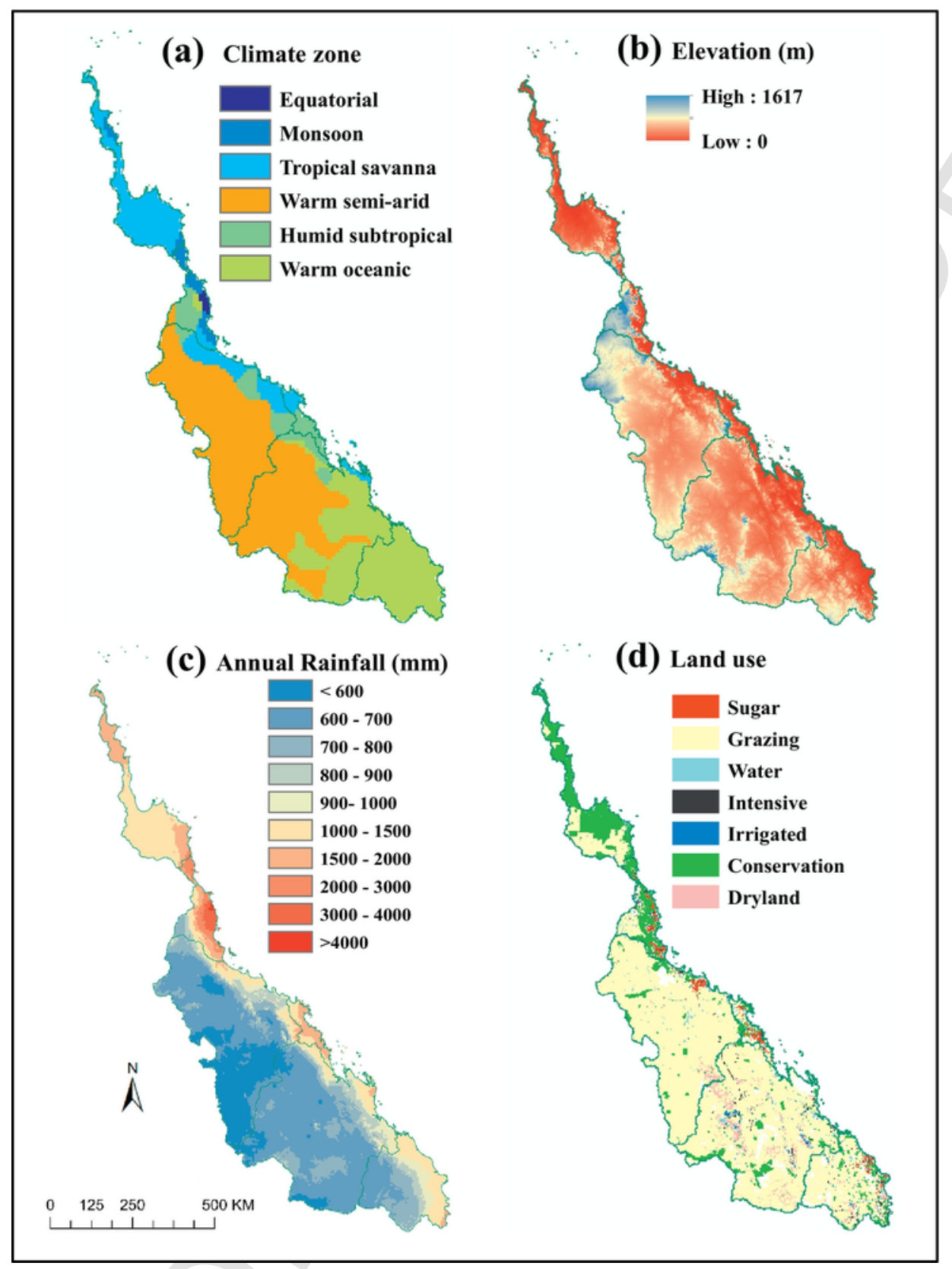

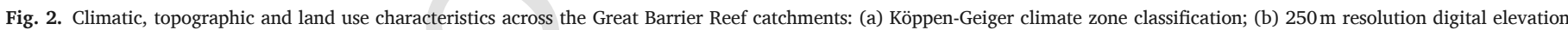
map (DEM); (c) annual rainfall; (d) land use.

Catchment topographic features (e.g., average slope, stream density and average elevation) and climatic and hydrological attributes (e.g., annual rainfall, temperature and runoff) were retrieved from the National Environmental Stream Attributes dataset (Version 1.1.5) (Bureau of Meteorology, 2011). Catchment soil erodibility, average soil total nitrogen and clay content were obtained from different geospatial data sets (Australian Soil Resource Information System, 2011; Queensland Government, 2017; Terrestrial Ecosystem Research Network, 2016).

\subsection{Data preparation}

The time-averaged constituent concentrations (i.e., average of all available sample concentrations for each constituent at each site) were calculated for each of the water monitoring sites. To justify the use of taking time-averaged constituent concentrations as the spatial repre- sentative of water quality response, the sampling distribution relative to the cumulative discharge in each water year (1st July to 30th June) was analysed. The information is further summarised in Fig. S-2, showing the percentage of samples falling into each $25 \%$ of cumulative discharge for each site. Although the samples are not perfectly uniformly distributed across the range of cumulative flow, there is a good coverage of all flow seasons (e.g., early, middle and late seasons) for the majority of sites. Moreover, there is no substantial difference in the distribution of samples across the cumulative discharge curve between the sites (Fig. $\mathrm{S}-2$ ), even though there is some variation due to either limited sample numbers or shorter monitoring periods (e.g., 1111019 Russell River at East Russell, 136004A Burnett River at Jones Weir Headwater, 136094A Burnett River at Jones Weir Tailwater and 136106A Burnett River at Eidsvold). Therefore, it is reasonable to assume that the time-averaged concentrations are a good representation of the spatial differences in water quality response. 
Table 1

Summary information for each monitored constituent (APHA, 2005; Wallace et al., 2016).

\begin{tabular}{|c|c|c|c|}
\hline $\begin{array}{l}\text { Monitored } \\
\text { constituents }\end{array}$ & Abbreviation & Analytical method & $\begin{array}{l}\text { Practical } \\
\text { quantification } \\
\text { limit }\end{array}$ \\
\hline $\begin{array}{l}\text { Total } \\
\text { suspended } \\
\text { solid }\end{array}$ & TSS & Gravimetric & $1 \mathrm{mg} / \mathrm{L}$ \\
\hline $\begin{array}{l}\text { Particulate } \\
\text { nitrogen }\end{array}$ & $\mathrm{PN}$ & $\begin{array}{l}\text { High-temperature-combustion } \\
\text { oxidation of suspended } \\
\text { sediment - persulfate } \\
\text { digestion }\end{array}$ & $0.03 \mathrm{mg} / \mathrm{L}$ \\
\hline $\begin{array}{l}\text { Oxidised } \\
\text { nitrogen }\end{array}$ & $\mathrm{NO}_{\mathrm{X}}$ & $\begin{array}{l}\text { Colorimetric (automated } \\
\text { cadmium reduction) method } \\
\text { (sum of nitrate and nitrite) }\end{array}$ & $0.001 \mathrm{mg} / \mathrm{L}$ \\
\hline $\begin{array}{l}\text { Ammonium } \\
\text { nitrogen }\end{array}$ & $\mathrm{NH}_{4}$ & $\begin{array}{l}\text { Colorimetric (automated } \\
\text { cadmium reduction) }\end{array}$ & $0.002 \mathrm{mg} / \mathrm{L}$ \\
\hline $\begin{array}{l}\text { Dissolved } \\
\text { organic } \\
\text { nitrogen }\end{array}$ & DON & $\begin{array}{l}\text { Subtracting particulate } \\
\text { nitrogen }(\mathrm{PN}) \text { ammonium } \\
\text { nitrogen }\left(\mathrm{NH}_{4}\right) \text { and oxidised } \\
\text { nitrogen }\left(\mathrm{NO}_{\mathrm{X}}\right) \text { from total } \\
\text { nitrogen }(\mathrm{TN})\end{array}$ & $0.03 \mathrm{mg} / \mathrm{L}$ \\
\hline $\begin{array}{l}\text { Filterable } \\
\text { reactive } \\
\text { phosphorus }\end{array}$ & FRP & Flow injection analysis & $0.001 \mathrm{mg} / \mathrm{L}$ \\
\hline $\begin{array}{l}\text { Dissolved } \\
\text { organic } \\
\text { phosphorus }\end{array}$ & DOP & $\begin{array}{l}\text { Subtracting filterable reactive } \\
\text { phosphorus (FRP) from } \\
\text { dissolved Kjeldahl phosphorus } \\
\text { (DKP) }\end{array}$ & $0.02 \mathrm{mg} / \mathrm{L}$ \\
\hline $\begin{array}{l}\text { Particulate } \\
\text { phosphorus }\end{array}$ & PP & $\begin{array}{l}\text { High-temperature-combustion } \\
\text { oxidation of suspended } \\
\text { sediment - persulfate } \\
\text { digestion }\end{array}$ & $0.02 \mathrm{mg} / \mathrm{L}$ \\
\hline $\begin{array}{l}\text { Electrical } \\
\text { conductivity }\end{array}$ & EC & Conductivity probes & $1 \mu \mathrm{S} / \mathrm{cm}$ \\
\hline
\end{tabular}

The time-averaged water quality data were then Box-Cox transformed (Box and Cox, 1964) to improve normality of variables for multivariate statistical analysis (Zhou et al., 2007a). The Box-Cox transformation parameters were different for each constituent. The Box-Cox transformed variables were more normally distributed, with the skewness being close to 0 for most water quality variables (Table S-6).

The log-sinh transformation was applied to all the catchment characteristics, to remove zeros in the raw data (e.g., land use data) (Wang et al., 2012). Table S-7 in the Supplementary materials summarises the kurtosis (i.e., a normal distribution has kurtosis exactly 3 (Westfall, 2014)) and skewness of catchment characteristics before and after log-sinh transformation. All the transformed catchment characteristics had an acceptable level of normality, based on $p$-value (all $p$-value $>0.01$ in Table S-7) of one-sample Kolmogorov-Smirnov test.

\subsection{Statistical analyses}

\subsubsection{Cluster analysis}

Hierarchical cluster analysis was used to test for spatial heterogeneity in constituent concentrations among the monitoring sites in the 32 Great Barrier Reef catchments. For each site, the Box-Cox transformed water quality variable were standardised to have a mean of 0 and standard deviation of 1 , to ensure the same scale for all water quality variables. Euclidean distances and Ward's linkage (Singh et al., 2004) algorithm were used in the cluster analyses, which was applied using MATLAB version R2017b (MATLAB and Statistics Toolbox, 2017).

A similar method was also applied to log-sinh transformed catchment characteristics. These data were also standardised before applying cluster analysis. The association of spatial patterns in water quality and catchment characteristics was investigated by checking if clusters derived from the two datasets were similar.
Table 2

Description and data source for catchment characteristics.

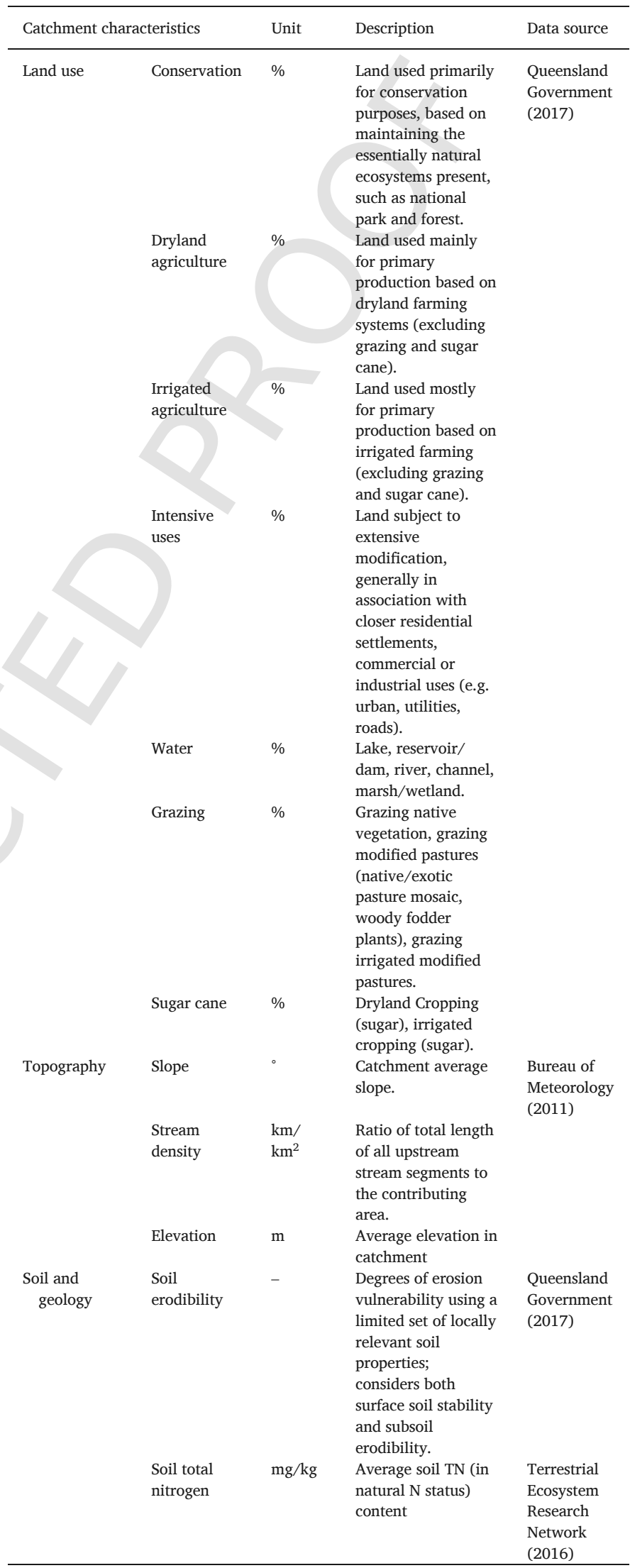


Table 2 (Continued)

\begin{tabular}{|c|c|c|c|c|}
\hline \multicolumn{2}{|c|}{ Catchment characteristics } & \multirow{2}{*}{$\begin{array}{l}\text { Unit } \\
\%\end{array}$} & \multirow{2}{*}{$\begin{array}{l}\text { Description } \\
\begin{array}{l}0-30 \mathrm{~cm} \text { soil layer } \\
\text { clay content }\end{array}\end{array}$} & \multirow{2}{*}{$\begin{array}{l}\text { Data source } \\
\text { Australian } \\
\text { Soil } \\
\text { Resource } \\
\text { Information } \\
\text { System } \\
(2011)\end{array}$} \\
\hline & Clay & & & \\
\hline \multirow[t]{3}{*}{$\begin{array}{l}\text { Climate and } \\
\text { hydrology }\end{array}$} & $\begin{array}{l}\text { Annual } \\
\text { rainfall }\end{array}$ & $\mathrm{mm}$ & $\begin{array}{l}\text { Average annual } \\
\text { rainfall in catchment }\end{array}$ & $\begin{array}{l}\text { Bureau of } \\
\text { Meteorology } \\
(2011)\end{array}$ \\
\hline & $\begin{array}{l}\text { Annual } \\
\text { temperature }\end{array}$ & ${ }^{\circ} \mathrm{C}$ & $\begin{array}{l}\text { Average annual } \\
\text { temperature in } \\
\text { catchment }\end{array}$ & \\
\hline & $\begin{array}{l}\text { Annual } \\
\text { runoff }\end{array}$ & ML & $\begin{array}{l}\text { Average surface } \\
\text { runoff in catchment }\end{array}$ & \\
\hline
\end{tabular}

\subsubsection{Principal component analysis and factor analysis}

Principal component analysis and factor analysis are powerful techniques to reduce the complexity derived from high dimensional datasets containing cross-correlated variables (Petersen et al., 2001; Singh et al., 2004). Most studies use the first few principal components (PCs) and rotate these to obtain a new set of factors that can be easily interpreted. This factor analysis further reduces the contribution of less significant variables obtained from a PCA and the new group of variables, known as varifactors (VFs), is extracted (Parinet et al., 2004; Shrestha and Kazama, 2007). The overall aim of this processing is to reduce the number of variables by combining the shared information in closely related variables and to produce more interpretable factors than PCA alone provides. The results in this study were interpreted using the loadings (i.e. coefficients of correlation between water quality/catchment characteristics and VFs) and scores (i.e., representing the relationship between samples and VFs).

We used a two-step PCA/FA on the transformed time-averaged water quality and catchment characteristics separately. The first PCA/FA was solely on the mean water quality constituents at each site. The second PCA/FA was on the catchment characteristics. We used $K$-means clustering method (see MacQueen (1967) and Hartigan and Wong (1979)) to assess the relationships between two PCA/FA scores, in order to quantitatively evaluate the relevance between features in two lower dimensional subspace (i.e., water quality and catchment characteristics). Several applications (e.g., remote sensing image classification, machine learning and pattern recognition) of PCA together with $K$-means clustering methods are given in Zha et al. (2002), $\mathrm{Ng}$ et al. (2002), Ding and He (2004) and Celik (2009).

Spearman's rank correlation coefficients (Spearman, 2010) between the scores defined by individual VFs from the two PCA/FAs were then calculated, aiming to identify the subset of catchment characteristics that led to the spatial homogeneity/heterogeneity in a group of average water quality responses. Based on the groups from the cluster analysis, we then examined the correlation between VFs scores (i.e., different water quality constituents with similar processes in catchments) in water quality and specific catchment characteristics, to further investigate the key natural and anthropogenic controls on spatial variability.

Similar to the cluster analysis, all the time-averaged transformed mean water quality variables and catchment characteristics were standardised to a mean of 0 and standard deviation of 1 , and the analyses (i.e., PCA/FA and $K$-means clustering) were performed in MATLAB version R2017b (MATLAB and Statistics Toolbox, 2017).

\section{Results}

\subsection{Cluster analysis}

The cluster analyses of both the water quality and catchment characteristics suggested that the 32 sites can be grouped into two clusters (Fig. S-3a \& b). There is good agreement between the two cluster analysis results (Fig. 3). Specifically, 8 out of the 32 sites are characterised as Cluster one in both analyses (blue round dots in Fig. 3), and 20 out of 32 sites are identified as Cluster two in both analyses (red triangles in Fig. 3). The clustering results differ for only 4 sites (blue triangles and red round dots in Fig. 3). The unusual sites might reflect the substantial contrast in specific land use between catchments. For example, 105107A at Normanby River in the Cape York region has considerable banana cultivation and associated fertiliser application, compared to other catchments (Howley et al., 2013). This strong agreement between the two cluster analyses indicates that the large-scale water quality spatial pattern is strongly associated with spatial pattern of catchment characteristics. In the following description, the cluster analysis refers to the cluster analysis of water quality responses.

Most of the Cluster one sites are located in the northern region of the Great Barrier Reef catchments. Here, climate (e.g., rainfall in particular), and land use patterns (e.g., fertiliser use on sugar cane) differ from the southern region where most Cluster two sites are situated. Cluster one sites have higher amounts of rainfall (Fig. S-5) and more frequent runoff events. In addition, the area of sugar cane proportionally greater in the catchments of these sites (Fig. S-4), compared with the southern monitoring sites. Cluster two sites are drier with grazing the strongly dominant land use (Davis et al., 2016).

The median values of average concentrations for Cluster one were lower than those of Cluster two sites except for $\mathrm{NO}_{\mathrm{X}}$ (Fig. 4). All water quality constituents except for NOx and EC, are statistically significantly different between the two clusters (two-sample $t$-test, $p<0.05$ ).

\subsection{Two-step PCA/FA}

\subsubsection{PCA/FA loadings}

The PCA/FA of water quality shows that the first 4 VFs (eigenvalues $>1$ before rotation), explain $90.7 \%$ of the total variance in time-averaged water quality (Table 3 ). In the following discussion, the loadings are classified as 'strong' (absolute loading above 0.75, red in Table 3), 'moderate' (absolute loading of 0.5-0.75, green) and 'weak' (absolute loading below 0.5, black) (Liu et al., 2003). A second PCA/FA was conducted, in order to link the factors in Table 3 to the catchment characteristics (land use, topography, geology, climatic and hydrological data). The first five VFs (eigenvalue $>1$ ) together account for $86.2 \%$ of the variance in original data set (Table 4).

It is useful to examine the key contributors to each VF. VF1 largely represents particulate constituents. VF2 represents most dissolved constituents. VF3 represents NOx. VF4 represents dissolved forms of phosphorus. The picture for the catchment characteristics is less clear due to strong interactions. VF1 (Table 4) is strongly dependent on several land uses (conservation, sugar and grazing), topography (slope and stream density), climate (annual rainfall) and soils (nitrogen fertility). High scores on VF1 are for coastal catchments with steep topography, dense stream networks, high rainfalls and relatively high sugar and conservation land uses. Sites with low values of VF1 scores tend to be more inland catchments with opposite characteristics. This illustrates the interactions between climate, topography and chosen land uses. VF2 picks up intensive land uses which tend to also be on less erodible soil. VF3 relates primarily to soil clay content and VF4 to dryland cropping, which correlates negatively with average temperature 


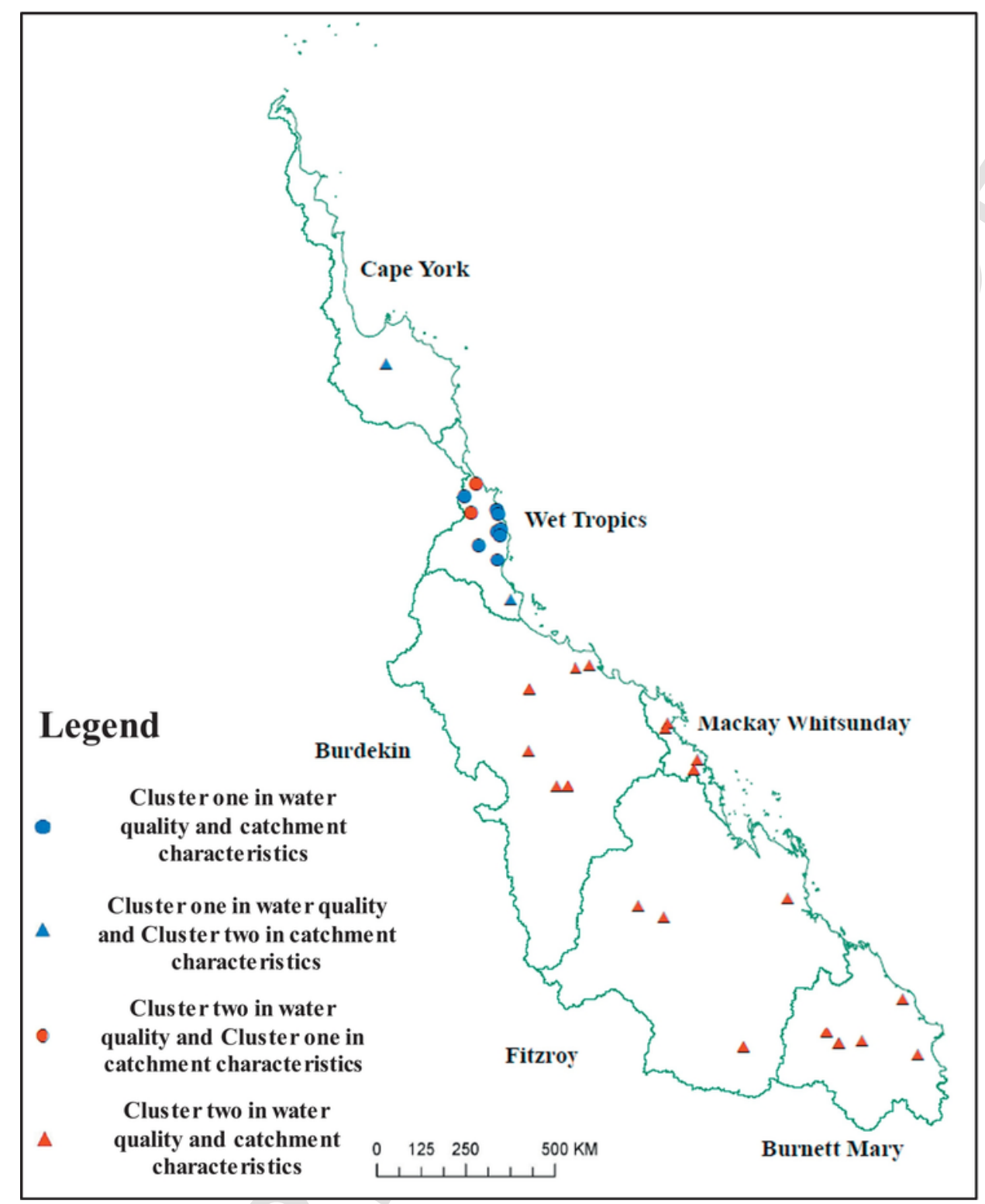

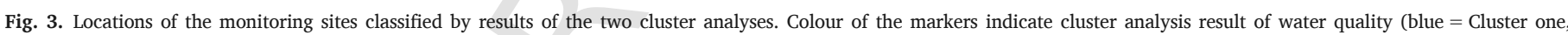

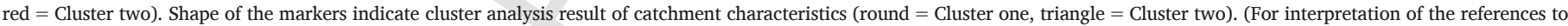
colour in this figure legend, the reader is referred to the web version of this article.)

(Table S-8). VF5 relates to sugar cane, which tends to be in high runoff catchments.

\subsubsection{Relationships between the PCA/FA scores}

To relate the spatial variability in water quality to catchment characteristics, the scores from two the PCA/FA results are investigated. Similar to the result for cluster analysis, the result of $K$-means clustering analysis of the two reduced dimensional datasets shows that, water quality-based clusters can be reproduced by catchment characteristics-based clusters (an overall $84.4 \%$ of matching rate in Table 5).

The correlation between scores at each site for different VFs (Table 6) shows that most correlation coefficients are low $(\rho<0.4)$, but there are statistically significant pairings. For instance, the scores of 'Particulate constituents' VF1 has a negative correlation with the scores on 'Mixed effect' VF1 in the catchment characteristics $(\rho=-0.61$, $p<0.01$ ). Furthermore, Fig. S- 6 shows that the separation of the two clusters identified in the water quality cluster analysis (red and blue dots) aligns with the variation in the catchment characteristic VF scores (Fig. S-6a). VF1 in the catchment characteristics PCA/FA results represented the largest variability in catchment characteristics, and most of the Cluster one sites are located in the positive domain, defined by VF1 in catchment characteristics (Fig. S-6a). While the majority of Cluster two sites are in the negative domain of scores on the VF1 in catchment characteristics.

Fig. 5 shows the relationships between score on 'Particulate constituent' VF1 and specific catchment characteristics identified based on Tables 4 and 6. Fig. 6 shows similar plots for 'Dissolved nitrogen' VF2. Together VF1 and VF2 represent the majority of variability (65.8\%) in the time-averaged water quality. Spearman's rank correlation coefficients between scores and catchment characteristics are shown for all sites (black), Cluster one (blue) and Cluster two (red) sites in Figs. 5 and 6. These show that, a stronger relationship is evident between 'Particulate constituent' VF1 and catchment characteristics when considering all sites together, while, individual clusters exhibit higher correlations between 'Dissolved nitrogen' VF2 scores and catchment characteristics (except for annual runoff Fig. 6a). 

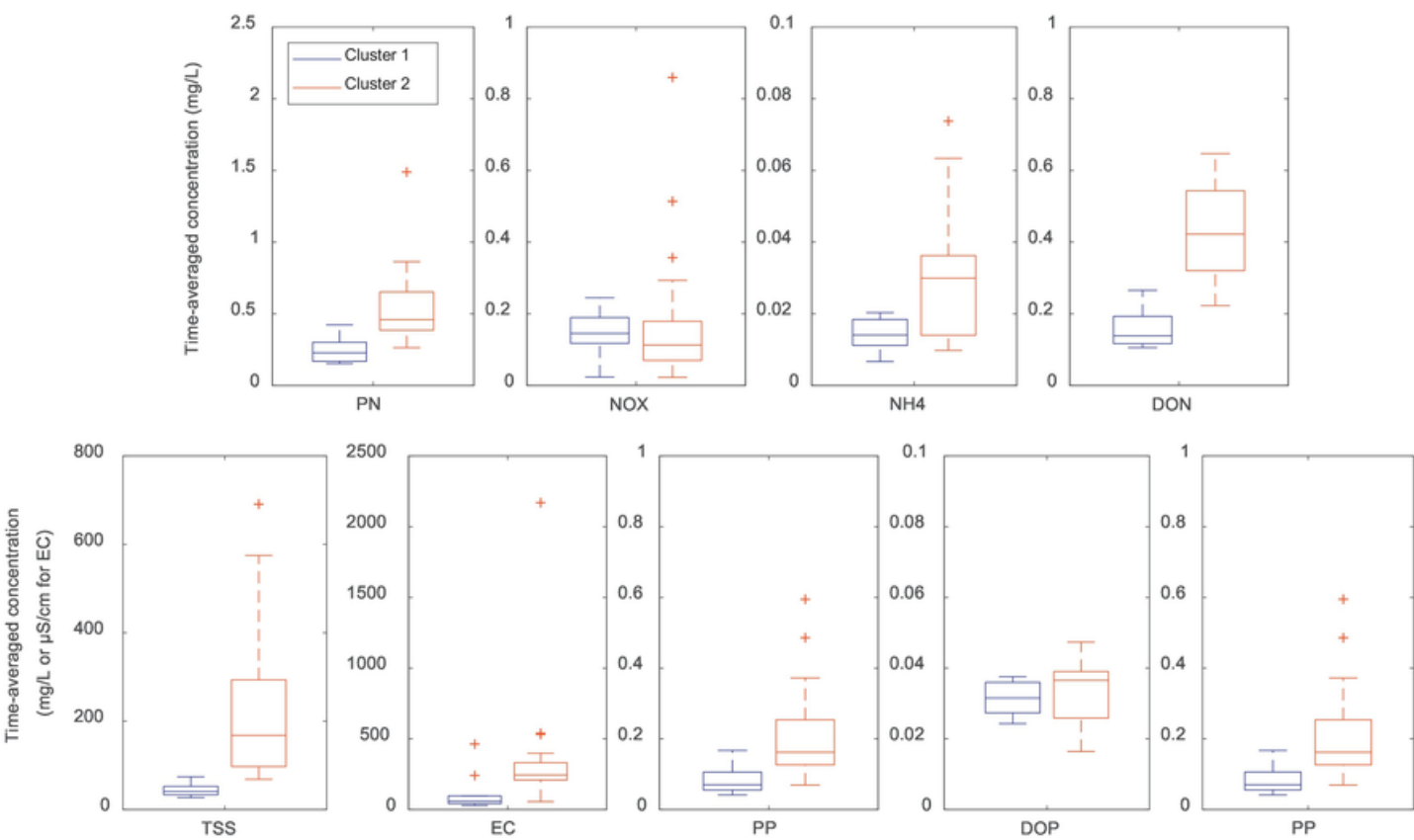

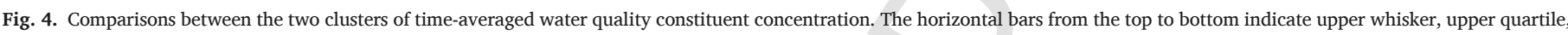
median, lower quartile and lower whisker, respectively. The plus mark indicates the outliers.

Table 3

Rotated component loadings (varimax) (Abdi, 2003) derived from PCA/FA of mean concentrations of water quality constituents.

\begin{tabular}{|c|c|c|c|c|c|}
\hline \multirow[t]{2}{*}{ Variable } & \multicolumn{4}{|c|}{ Loading } & \multirow[t]{2}{*}{ \% Variance explained } \\
\hline & VF1 & VF2 & VF3 & VF4 & \\
\hline TSS & 0.94 & 0.20 & -0.12 & 0.12 & 94.6 \\
\hline PN & 0.94 & 0.22 & -0.01 & 0.00 & 93.5 \\
\hline $\mathrm{NO}_{x}$ & -0.03 & 0.10 & 0.98 & 0.06 & 97.1 \\
\hline $\mathrm{NH}_{4}$ & 0.04 & 0.88 & 0.33 & 0.01 & 88.8 \\
\hline DON & 0.48 & 0.78 & 0.01 & 0.12 & 84.9 \\
\hline FRP & 0.66 & 0.53 & 0.20 & 0.31 & 85.5 \\
\hline DOP & 0.12 & 0.12 & 0.05 & 0.98 & 98.7 \\
\hline PP & 0.97 & 0.09 & 0.03 & 0.08 & 95.2 \\
\hline EC & 0.18 & 0.85 & -0.11 & 0.10 & 77.5 \\
\hline Eigenvalue & 3.42 & 2.50 & 1.14 & 1.10 & \\
\hline$\%$ Variance explained & 38.0 & 27.8 & 12.7 & 12.2 & \\
\hline$\%$ Cumulative & 38.0 & 65.8 & 78.4 & 90.7 & \\
\hline
\end{tabular}

Note. $\mathrm{VF}=$ varifactor (rotated components using varimax method).

Strong loadings in bold and red; moderate loadings in bold and green.

\section{Discussion}

\subsection{Spatial pattern in water quality responses}

There are strong patterns in time-averaged water quality responses. Cluster analysis reveals that monitoring sites can be grouped based on similarity in their average water quality for each of the 9 constituents considered (Figs. 3, 4 and S-3a). Cluster one sites have lower average concentrations of all constituents except $\mathrm{NO}_{\mathrm{X}}$ (Fig. 4), with most of these sites are located in the northern region, where the converse is true for the Cluster two sites. This spatial pattern is evident when evaluating the spatial distribution of VFs scores defined in PCA/FA on water quality (Fig. 7). Sites with high 'Particulate constituents' VF1 scores (Fig. 7a) are mostly Cluster two sites. The spatial patterns of 'Dissolved nitrogen' VF2 and 'Dissolved phosphorus' VF4 scores are not as evident as VF1, and the average scores of the Cluster two sites for these two VFs are higher than those of Cluster one sites (Table S-10). The
'NOx' VF3 score is higher for the Cluster one sites and several sites in the Fitzroy (Fig. 7d).

The spatial pattern in water quality is strongly linked to catchment characteristics, as the cluster analyses using water quality and catchment characteristics largely agree (Fig. 3). Cluster one sites are mainly located in coastal catchments in the Wet Tropics region with high annual rainfall and streamflow that is likely to dilute concentrations. These catchments have a mix of conservation, grazing, sugar cane and other intensive land uses (Fig. S-4). In contrast, Cluster two sites are dominated by grazing land with small amounts of conservation, sugar and rain-fed extensive cropping. Cluster one sites are much wetter (i.e., higher annual rainfall) than the Cluster two sites. Topography (Fig. $S-5)$ tends to show a clear difference between the two clusters ( $t$-test, $p<0.05$ ).

VF1 for catchment characteristics is most strongly related to cluster analysis on water quality (Table 6 and Fig. S-6a). This indicates that there is a mix of spatial catchment characteristics controlling spatial variability in water quality. There are both mechanistic links and cross- 
Table 4

Rotated component loading (varimax) derived from PCA/FA of catchment characteristics.

\begin{tabular}{|c|c|c|c|c|c|c|c|}
\hline \multicolumn{2}{|l|}{ Variable } & \multicolumn{5}{|c|}{ Loading } & \multirow{3}{*}{$\begin{array}{l}\text { \% Variance explained } \\
93.2\end{array}$} \\
\hline & & \multirow{2}{*}{$\begin{array}{l}\text { VF1 } \\
0.76\end{array}$} & \multirow{2}{*}{$\begin{array}{l}\text { VF2 } \\
0.33\end{array}$} & \multirow{2}{*}{$\begin{array}{l}\text { VF3 } \\
0.03\end{array}$} & \multirow{2}{*}{$\begin{array}{l}\text { VF4 } \\
-0.07\end{array}$} & \multirow{2}{*}{$\begin{array}{l}\text { VF5 } \\
0.49\end{array}$} & \\
\hline \multirow{7}{*}{ 状 } & Conservation & & & & & & \\
\hline & Dryland agriculture & -0.42 & 0.03 & 0.48 & 0.57 & -0.09 & 74.5 \\
\hline & Irrigated agriculture & 0.20 & 0.78 & -0.06 & 0.24 & -0.26 & 78.3 \\
\hline & Intensive uses & 0.28 & 0.84 & 0.05 & 0.22 & 0.02 & 84.0 \\
\hline & Water & 0.68 & 0.20 & -0.58 & 0.06 & 0.07 & 83.0 \\
\hline & Grazing & -0.94 & -0.17 & -0.06 & 0.06 & -0.05 & 92.8 \\
\hline & Sugar cane & 0.72 & 0.05 & -0.28 & -0.21 & -0.52 & 91.6 \\
\hline \multirow{3}{*}{$\begin{array}{l}\text { 츨 } \\
\text { 응 } \\
\text { 응 }\end{array}$} & Slope & 0.94 & 0.12 & 0.00 & -0.01 & 0.15 & 92.2 \\
\hline & Stream density & 0.81 & 0.41 & -0.08 & -0.29 & 0.08 & 92.6 \\
\hline & Mean elevation & 0.13 & 0.70 & 0.09 & 0.18 & 0.45 & 75.7 \\
\hline \multirow{3}{*}{ 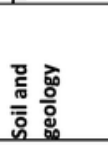 } & Soil erodibility & -0.40 & -0.72 & -0.04 & 0.28 & -0.24 & 81.0 \\
\hline & Mean TN & 0.81 & 0.46 & 0.22 & 0.21 & 0.10 & 97.4 \\
\hline & Clay & 0.25 & 0.13 & 0.84 & 0.21 & -0.12 & 84.5 \\
\hline \multirow{3}{*}{ 兽 } & Annual rainfall & 0.93 & 0.29 & 0.01 & -0.19 & 0.05 & 97.9 \\
\hline & Annual temperature & 0.07 & -0.30 & -0.12 & -0.85 & -0.06 & 83.0 \\
\hline & Annual runoff & 0.27 & 0.04 & -0.39 & -0.03 & 0.75 & 75.6 \\
\hline \multicolumn{2}{|l|}{ Eigenvalue } & 6.13 & 3.09 & 1.58 & 1.53 & 1.45 & \\
\hline \multicolumn{2}{|c|}{ \% Variance Explained } & 38.3 & 19.3 & 9.9 & 9.6 & 9.1 & \\
\hline \multicolumn{2}{|c|}{$\%$ Cumulative } & 38.3 & 57.6 & 67.5 & 77.1 & 86.2 & \\
\hline
\end{tabular}

Note. $\mathrm{VF}=$ varifactor (rotated components using varimax method).

Strong loadings in bold and red; moderate loadings in bold and green.

Table 5

Classification matrix for $K$-means clustering analysis of scores from two PCA/FA.

\begin{tabular}{|c|c|c|c|}
\hline \multirow[t]{2}{*}{$\begin{array}{l}\text { Clusters assigned by scores of } 5 \\
\text { catchment characteristics VFs }\end{array}$} & \multirow[t]{2}{*}{$\begin{array}{l}\% \\
\text { matching }\end{array}$} & \multicolumn{2}{|c|}{$\begin{array}{l}\text { Clusters assigned by scores } \\
\text { of } 4 \text { water quality VFs }\end{array}$} \\
\hline & & Cluster one & Cluster two \\
\hline Cluster one & $92.3 \%$ & 12 & 1 \\
\hline Cluster two & $78.9 \%$ & 4 & 15 \\
\hline$\%$ overall matching & $84.4 \%$ & & \\
\hline
\end{tabular}

correlation between catchment characteristics (Table S-8) (Arheimer and Liden, 2000; Lintern et al., 2018). Further discussion of the association between water quality and catchment characteristics is provided later in the discussion.

\subsection{Groups of constituents with similar time-averaged spatial behaviours}

The 9 constituents can be divided into four groups with distinct time-averaged spatial patterns of constituent concentrations according to the PCA/FA analysis (Table 3), indicating that there are constituents with common behaviour. The separation of the four groups of constituents indicates that there are systematic differences in the source, processing and/or transport of these constituents compared with the other constituent groups.

VF1, representing the largest proportion of variability (38\%), has strong positive loadings on TSS, PN and PP, which are all particulate. Although it is a dissolved compound, FRP has a medium positive loading. This might be caused by in-stream release of inorganic phosphorus from sediments to which they were bound before entering the streams (Gardolinski et al., 2004; Haygarth and Jarvis, 2002). VF2 (27.8\% of total variability), has strong positive loadings on dissolved nitrogen $\left(\mathrm{NH}_{4}\right.$ and DON, but excluding $\mathrm{NO}_{\mathrm{X}}$ ), and salinity (EC). This may be associated with hydrological transport processes (Hrachowitz et al., 2016), including discharge between surface water and groundwater for EC, and in-stream biogeochemical processes (e.g., nutrient cycling) for dissolved forms of nitrogen (Dawson et al., 2001; Mulholland and Hill, 1997). VF3 and VF4 explain $12.7 \%$ and $12.2 \%$ of observed variability in time-averaged water quality, respectively. $\mathrm{NO}_{\mathrm{X}}$ and $\mathrm{DOP}$ are strongly loaded on these two factors, respectively. The importance of NOx in

Table 6

Spearman's rank correlation between scores on VFs defined by the two PCA/FA.

\begin{tabular}{|c|c|c|c|c|c|}
\hline & & PCA/FA for water quality & & & \\
\hline & & 'Particulate constituents' VF1 & 'Dissolved nitrogen' VF2 & 'NOx' VF3 & 'Dissolved phosphorus' VF4 \\
\hline \multirow[t]{5}{*}{ PCA/FA for catchment characteristics } & 'Mixed effect’ VF1 & $-0.61^{* * *}$ & -0.18 & $0.43^{* *}$ & -0.21 \\
\hline & 'Intensive uses' VF2 & -0.02 & -0.32 & -0.02 & $-0.36^{*}$ \\
\hline & ‘Soil clay’ VF3 & 0.12 & -0.07 & 0.05 & -0.15 \\
\hline & 'Temperature' VF4 & 0.16 & 0.34 & 0.14 & -0.01 \\
\hline & 'Runoff' VF5 & -0.08 & $-0.45^{* *}$ & -0.28 & 0.05 \\
\hline
\end{tabular}

Note. $\mathrm{VF}=$ varifactor (rotated components using varimax method).

$* p<0.05$.

** $p<0.01$. 

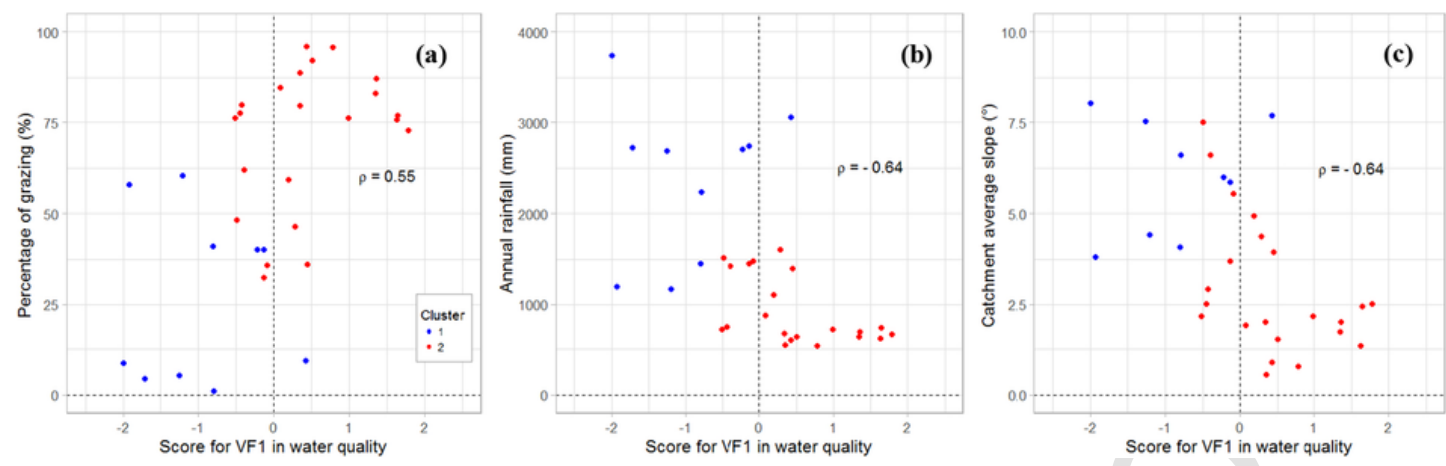

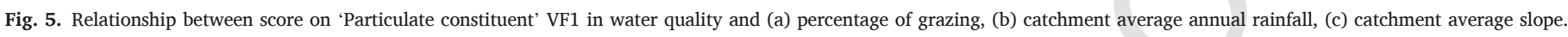

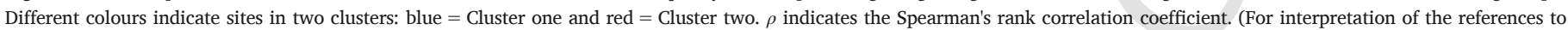
colour in this figure legend, the reader is referred to the web version of this article.)
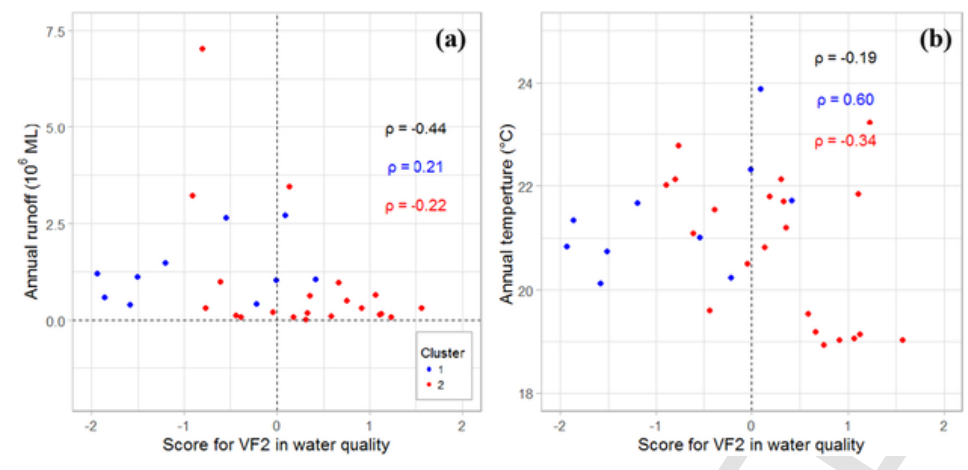

b)

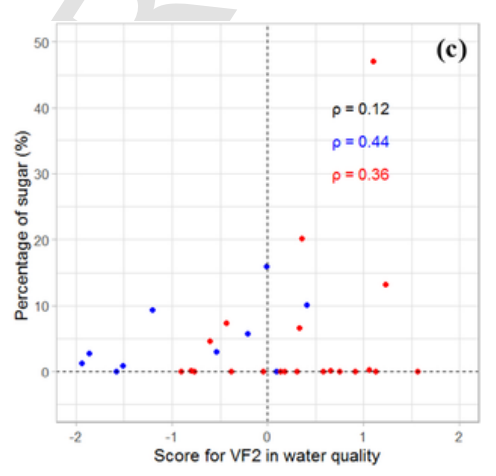

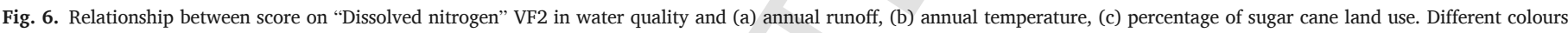

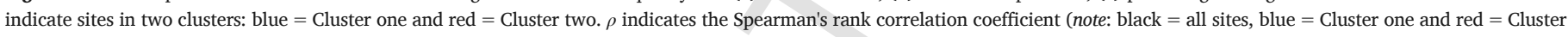
two). (For interpretation of the references to colour in this figure legend, the reader is referred to the web version of this article.)

the results reflects the effect of particular land uses (discussed in Section 4.3.3, Oxidised nitrogen).

\subsection{Examining the association between water quality spatial variability and catchment characteristics}

Five factors were identified in the second PCA/FA (Table 4) that explain about $86 \%$ of the variability in catchment characteristics and that reduce the 16 inter-related catchment characteristics to five independent factors. The characteristics with strong loadings on VF1 (explaining $38.3 \%$ of variance) are land uses, topography, and climate and hydrology. The strong cross-correlation between different catchment characteristics (Table S-8) explains these diversity of catchment characteristics included in this latent factor. For example, flatter, drier more inland catchments are dominated by grazing (slope and grazing: $\rho=-0.89$, $p<0.01$ ) and the physiographic characteristics have strongly influenced the land use.

\subsubsection{Sediments and particulate nutrients}

The strong association between 'Particulate constituents' water quality factor and the 'Mixed effect' catchment characteristic factor reveals a combined effect of land use and various physiographic properties on sediments and particulate nutrients, in particular the grazing land use (Table 6). Given the range of important characteristics in the 'Mixed effect' factor, there is likely to be multiple factors influencing the spatial variation in sediment concentration. The positive relationship between the percentage of grazing and the score on 'Particulate constituent' VF1 (Fig. 5a) may be explained by the fact that the high proportion of cattle grazing tends to result in a higher rate of soil erosion, leading to an increase suspend sediment sourced from gully, streambank and hillslope erosions (Liu et al., 2017; McKergow et al.,
2005; Turner et al., 2012). Rainfall erosivity is an important driver of erosion but annual rainfall (and erosivity) is lower in the catchments with higher sediment concentrations (Fig. 5b). In the drier catchments, events are typically separated by long dry periods, resulting in highly ephemeral flow and sporadic runoff events with higher peak sediment concentrations during the 'first-flush' in dry-tropical rivers (Davis et al., 2016; Packett et al., 2009). This counter-intuitive relationship with spatial rainfall and the 'first-flush' effect suggests that lower vegetation cover interacting with rainfall events may be the important influencing processes, rather than rainfall erosivity.

All else being equal, high topographic slope is expected to lead to greater erosion by any surface flows and better delivery to stream, although high slope should also preference subsurface flow over surface flow. Counterintuitively, the data (Fig. 5c) shows a negative relationship between the 'Particulate constituent' VF1 score and catchment slope. This unexpected effect of slope could be explained by the correlations with other catchment characteristics, rather than being a causal factor in the spatial variation of sediment concentrations. For example, most of the flat catchments (Cluster two sites) are inland catchments, where a large proportion of grazing land might act as a source of sediment. This finding is supported by a regional study in Fitzroy River catchment, which found that the high fine sediment concentrations during the event were closely associated with a high percentage of rainfall on cropping (Packett et al., 2009).

\subsubsection{Dissolved nitrogen and salinity}

The 'Dissolved nitrogen' score (VF2) correlates with both the 'Runoff' (VF5) and 'Temperature' (VF4) factors (Table 6). Catchment climate and hydroclimatic characteristics, such as annual runoff (Fig. 6a) and annual temperature (Fig. 6b), have considerable contributions to these two VFs. Previous studies showed that these catchment charac- 


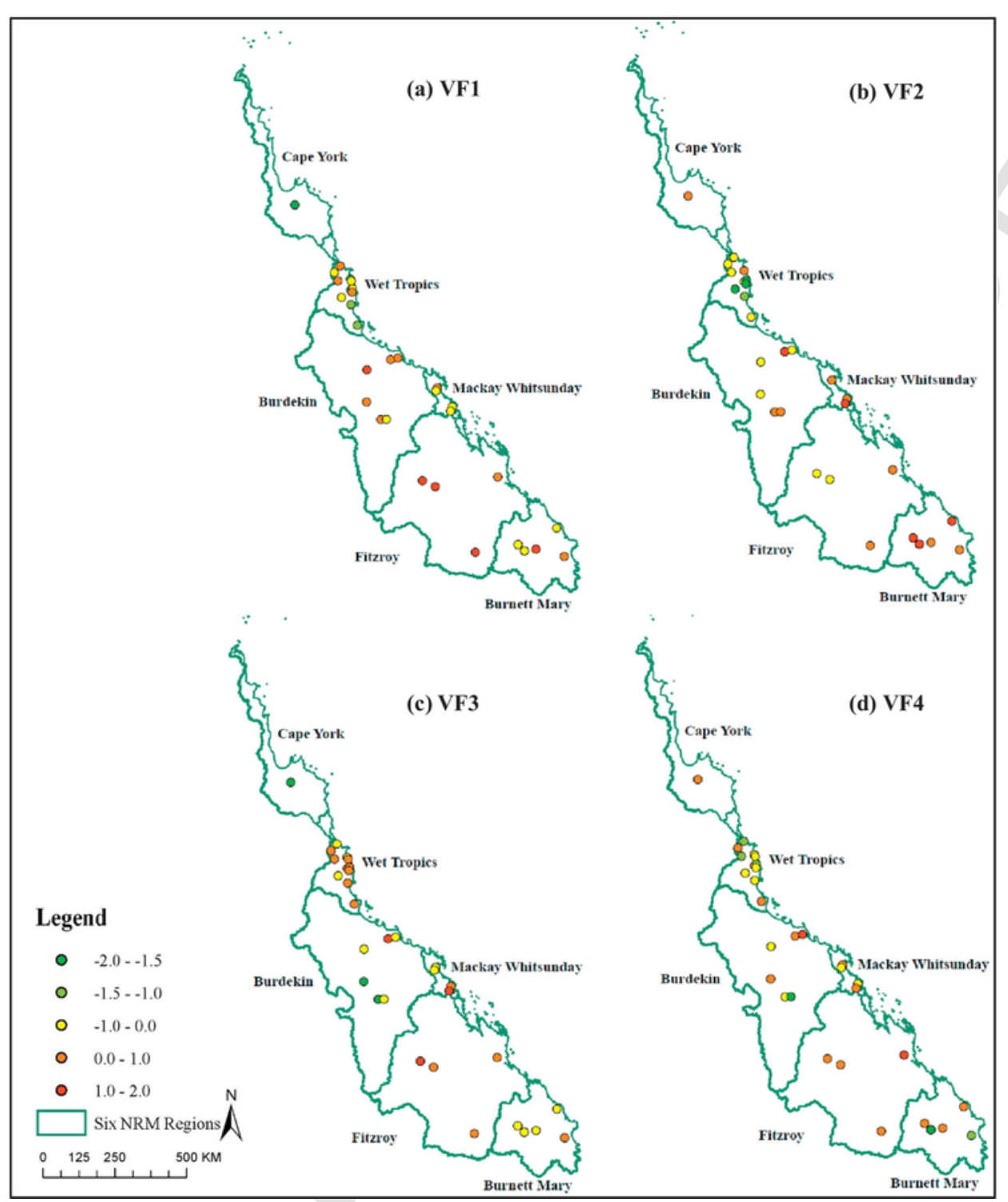

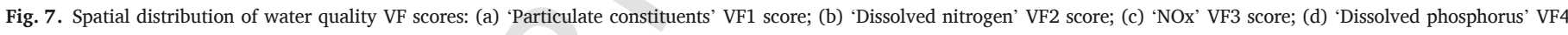
score.

teristics could influence the mobilisation and transport of dissloved nitrogen and EC (e.g., mineralistaion of organic matter or desorption form particulates, and transportation of EC in the sub-surface flow pathway) (Donnelly et al., 2011; Fritz and Anderson, 2013; Lintern et al., 2018). Indeed, we found a significant and negative correlation for both mean annual runoff and temperature with DON and $\mathrm{NH}_{4}$ and EC (Table S-9).

There is a negative correlation between annual runoff and VF2 scores (Fig. 6a), and the difference in the level of the VF2 scores for the two clusters suggests contrasting hydrologic behaviours (e.g., hydrological variability) of the streams. The comparison of flow duration curves (daily flow depth in $\mathrm{mm}$ calculated from daily discharge data obtained from the Department of Natural Resources, Mines and Energy, Water Monitoring Information Portal, Fig. 8a) show that the majority of the Cluster one sites (i.e., blue curves in Fig. 8a) feature perennial characteristics with less variability in daily streamflow compared with the Cluster two sites (i.e., red curves in Fig. 8a). The Cluster two sites with higher coefficient of variation of daily flow depth than Cluster one sites (Fig. 8b). This indicates that the perennial Cluster one streams are in areas with higher runoff coefficients and thus more leaching. As a re- sult, dissolved nitrogen and EC could be transported more broadly across the catchment, thus lowering the average concentrations. In contrast, the majority of streams of the Cluster two sites are ephemeral rivers (i.e., red curves in Fig. 8a and red dots in Fig. 8b), and the more variable with longer low flow period may lead to a changing source of surface runoff, by providing more groundwater with high salinity that differs chemically from stream water (Moore et al., 2008).

Interestingly, the relationships between scores on 'Dissolved nitrogen' VF2 in water quality and annual temperature (Fig. 6b) differ between the two clusters (significantly different according to 10,000 bootstrap testing on the test statistic - difference in two correlation coefficients, and the $95 \%$ confident interval is away from 0). The positive effect of temperature on 'Dissolved nitrogen' VF2 for the Cluster one sites (blue scatters in Fig. $6 \mathrm{~b}, \rho=0.60$ ) score is likely due to the cross-correlation between climate and land uses in different catchments. Higher annual temperature favours sugar cane growth, leading to an increase in scores on 'Dissolved nitrogen' VF2 when annual temperature is higher. In contrast, the negative relationship between annual temperature and scores on 'Dissolved nitrogen' VF2 for cluster two sites $(\rho=-0.34)$ land use and cover have an impact on dissolved ni- 

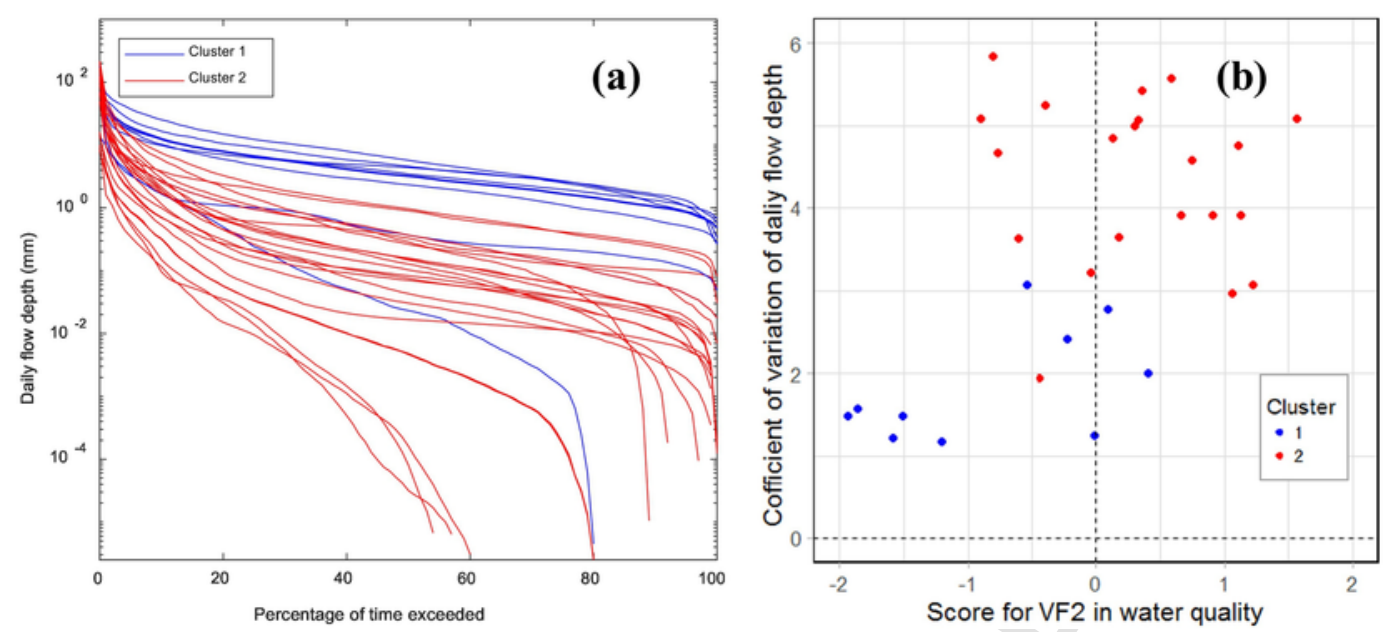

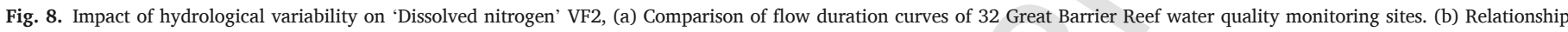

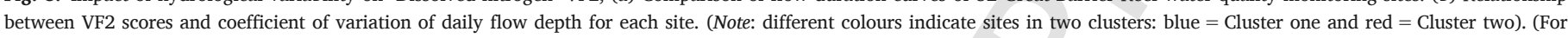
interpretation of the references to colour in this figure legend, the reader is referred to the web version of this article.)

trogen in runoff. For example, Brigalow Belt regions (e.g., Fitzroy and Burdekin), where these is a broad-scale inclusion of virgin brigalow woodland into agricultural uses (e.g., pasture legumes), has been identified as a major source of dissolved organic nitrogen (Allen et al., 2016; Elledge and Thornton, 2012, 2017). Sugar cane (Cluster two sites, blue dots in Fig. 6c) where excessive fertiliser might be applied, is another nitrogen contributor associated with $\mathrm{NH}_{4}$ (Davis et al., 2016). In addition, it is argued that higher temperatures could favour denitrifying bacteria, thus reducing the level of ammonium nitrogen in the catchments (Smith et al., 1997).

\subsubsection{Oxidised nitrogen}

A distinct constituent, $\mathrm{NO}_{\mathrm{X}}$, identified in the final $\mathrm{VF}$ in water quality, appears to be linked to 'Mixed effect' VF1 of catchment characteristics PCA/FA (Table 6, $\rho=0.43$ ). While this is also true of the particulates, the direction of correlation is opposite. Table 4 and Table S-9 show that sugar cane followed by stream density and annual rainfall are the three main characteristics positively correlated with the spatial variability in $\mathrm{NO}_{\mathrm{X}}$. This result is not unexpected as Biggs et al. (2013) and Mitchell et al. (2005) have previously shown that for catchments in the Mackay-Whitsunday region, the majority of $\mathrm{NO}_{\mathrm{X}}$ losses from the catchment occur via deep drainage and runoff derived coupled with sugar cane plantations, where high nitrogenous fertilisers are applied. Regions such as the Wet Tropics and Mackay-Whitsunday, have a high proportion of sugar cane and horticultural cropping ( $>8 \%$ of the catchment area). This further suggests that nitrogenous fertilisers are an important source of $\mathrm{NO}_{\mathrm{X}}$ in these catchments (Azizian et al., 2015; Mitchell et al., 2005; Reddy et al., 1989). The positive correlation between 'Oxidised nitrogen' VF3 score and stream density $(\rho=0.44)$ and annual rainfall ( $\rho=0.38$ ) indicates that $\mathrm{NO}_{\mathrm{X}}$ might be transported where stream networks are well-developed in relatively wet catchments, reducing the residence time of $\mathrm{NO}_{\mathrm{X}}$ and thus resulting in a higher riverine oxidised nitrogen concentration (Edwards and Withers, 2008; Liu et al., 2017).

\subsubsection{Dissolved phosphorus}

Table 6 shows that the 'Dissolved organic phosphorus' VF4 score (Table 3 ) is significantly and negatively correlated to 'Intensive uses' VF2 score (Table 4$)$ in the second PCA/FA $(\rho=-0.36)$. A negative correlation between DOP and these two land use categories (i.e., intensive and irrigated land uses) is also found (Table S-9). In contrast, other studies (Chantigny, 2003; Kroon et al., 2012; Mattsson et al., 2005; Palviainen et al., 2016) showed that dissolved phosphorus concentra- tion was positively correlated with catchments with a higher proportion of cropping agriculture (non-point source), sewage treatment plants or industrial discharges (point source). The contrasting results might be explained by the scale of monitored catchments in this study being so large that the input of DOP associated with the specific land uses (e.g., source from animal waste) might not be detectable (Hunter and Walton, 2008). In addition, the biogeochemical cycling and associated transport of dissolved phosphorus (e.g., DOP) might lead to the spatial heterogeneity in 'Dissolved organic phosphorus' VF4 score (Fig. 7c) (Robson, 2014; Vadas et al., 2005).

\subsection{Management practice implications}

Over the past decade, the Reef Water Quality Protection Plan (Brodie et al., 2013) led to the introduction of specific regulations and incentives for the adoption of the improved management practices in the Great Barrier Reef catchments (Waters et al., 2014). Farmer has been encouraged to implement these to minimise the risk of fine sediments and nutrients inputs to the Great Barrier Reef marine ecosystem (Thorburn et al., 2013).

The original water management plan was based on a range of lines evidence that suggested large grazing catchments were targets in reducing sediments (e.g., protection from soil erosion processes) and key management practices were adopted to control DIN exported from sugar cane land use (Stephen Lewis et al., 2014; Waters et al., 2014). The monitoring data analysed here were collected to further understand loads and patterns of loads at the catchment-basin scale. Our results are consistent with the current understanding developed at smaller scales that shows land use and management practices are important factors affecting the spatial variability in water quality responses (Brodie et al., 2017; Hunter and Walton, 2008; Lynam et al., 2010; Thorburn et al., 2013). Grazing land use has a strong association with spatial variation in sediments and particulate nutrients across the Great Barrier Reef catchments, with particulates being identified as a key source of impact on the Great Barrier Reef aquatic environment. A continued concentration on management of sediments in the large grazing catchments is supported by our results. In addition, there is a strong correlation between the area of sugar cane and dissolved inorganic nitrogen concentrations. Again, our results support continued focus on intensive agriculture, in particular sugar cane, in addressing $\mathrm{NO}_{\mathrm{X}}$ impact on the Great Barrier Reef. Finally, catchment topographic characteristics, interacting with land uses, might also influence these different types of constituents. In particular, the results suggest that fo- 
cusing fertiliser management on catchments with high stream density and annual rainfall (strong hydrologic connectivity) and sugar cane activities might be worth more in-depth investigation to establish, if real benefits could be achieved in reducing dissolved inorganic nitrogen in streams.

Catchment climate and hydrology affect spatial variability in dissolved nitrogen species (except for $\mathrm{NO}_{\mathrm{X}}$ ) and salinity. This is likely a result of cross-correlation of these catchment characteristics and land uses and catchment geology. We also found that the relationship of the spatial pattern of the main dissolved constituents (e.g., dissolved nitrogen and EC) and catchment characteristics differs for the two clusters of sites across the Great Barrier Reef catchments. A sound understanding of the underlying reasons for the differences in these relationships is necessary for effective water quality management policy-making. Indeed, the hydrological variability, in-stream biogeochemical processes, as well as sources from different land uses have been found to be significant factors that can lead to varying behaviours of dissolved nitrogen and EC among two clusters of sites. This implies that there is not a 'one-size-fits-all' approach to managing water quality throughout the whole the Great Barrier Reef catchments. It should also be noted that pesticides have been identified as important water quality parameters in the context of the Great Barrier Reef catchments, but that they are excluded from this study.

\section{Conclusions}

This study applied multivariate statistical techniques to understand the spatial variability in stream water quality in the Great Barrier Reef catchments. We found that different catchment characteristics influenced the magnitude of concentration in varying ways in the Great Barrier Reef catchments. The influences of the key catchment characteristics depended on clusters of sites and their impacts differed for different constituents. Therefore, a comprehensive understanding of spatial variability and its association with catchment characteristics is likely to provide valuable information for catchment management make decisions aiming to address the risks of land-derived constituents on the marine aquatic ecosystem. It is important to note that water quality varies in time, as well as space, and temporal drivers (e.g., discharge, spatial and temporal differences in land use and management and cover, etc.) of water quality variation in these catchments is the subject of ongoing investigation to improve our understanding of water quality dynamics.

\section{Acknowledgements}

This study was supported by the Australian Research Council (LP140100495), the EPA Victoria, the Victorian Department of Environment, Land, Water and Planning, Bureau of Meteorology and Queensland Natural Resources and Mines. The authors would like to acknowledge the efforts of the Queensland Department of Environment and Science who provided the water quality monitoring data. The author would also like to offer sincere gratitude to Ms. Jie Jian for her assistance in geospatial database compilation. Dr. Paul Leady, Mr. Malcolm Watson, Dr. Ulrike Bende-Michl, Dr. Paul Wilson, and Ms. Belinda Thompson all provided valuable advice in the preparation of this manuscript.

\section{Appendix A. Supplementary data}

Supplementary data to this article can be found online at https:// doi.org/10.1016/j.marpolbul.2018.10.019.

\section{References}

Abdi, H., 2003. Factor rotations in factor analyses. In: Encyclopedia for Research Methods for the Social Sciences. Sage, Thousand Oaks, CA, pp. 792-795.

Alberto, W.D., Del Pilar, D.M., Valeria, A.M., Fabiana, P.S., Cecilia, H.A., De Los Ángeles, B.M., 2001. Pattern recognition techniques for the evaluation of spatial and temporal variations in water quality. A case study: Suquía River Basin (Córdoba-Argentina). Water Res. 35 (12), 2881-2894.

Allan, J., Bain, M., Pestegaard, K., Richter, B., Sparks, R., 1997. The Natural Flow Regime: A Paradigm for River Conservation.

Allen, D., Pringle, M., Butler, D., Henry, B., Bishop, T., Bray, S., Orton, T., Dalal, R., 2016. Effects of land-use change and management on soil carbon and nitrogen in the Brigalow Belt, Australia: I. Overview and inventory. Rangel. J. 38 (5), 443-452.

APHA, 2005. Standard Methods for the Examination of Water and Wastewater. American Public Health Association (APHA), Washington, DC, USA.

Arheimer, B., Liden, R., 2000. Nitrogen and phosphorus concentrations from agricultural catchments-influence of spatial and temporal variables. J. Hydrol. 227 (1-4), 140-159.

Aronson, R.B., Hilbun, N.L., Bianchi, T.S., Filley, T.R., Mckee, B.A., 2014. Land use, water quality, and the history of coral assemblages at Bocas del Toro, Panama. Mar. Ecol. Prog. Ser. 504, 159-170.

Australian Soil Resource Information System, 2011. ASRIS 0-30 cm clay content $(250 \mathrm{~m}$ raster). Retrieved 05/07/2016 http://www.asris.csiro.au/themes/NationalGrids. html.

Ayers, R.S., Westcot, D.W., 1985. Water Quality for Agriculture. vol. 29, Food and Agriculture Organization of the United Nations, Rome.

Azizian, M., Grant, S.B., Kessler, A.J., Cook, P.L., Rippy, M.A., Stewardson, M.J., 2015 Bedforms as biocatalytic filters: a pumping and streamline segregation model for nitrate removal in permeable sediments. Environ. Sci. Technol. 49 (18), 10993-11002.

Biggs, J., Thorburn, P., Crimp, S., Masters, B., Attard, S., 2013. Interactions between climate change and sugarcane management systems for improving water quality leaving farms in the Mackay Whitsunday region, Australia. Agric. Ecosyst. Environ. 180, $79-89$.

Box, G.E., Cox, D.R., 1964. An analysis of transformations. J. R. Stat. Soc. Ser. B Methodol. 211-252.

Bricker, S.B., Rice, K.C., Bricker, O.P., 2014. From headwaters to coast: influence of human activities on water quality of the Potomac River Estuary. Aquat. Geochem. 20 (2-3), 291-323.

Brodie, J., Fabricius, K., De'ath, G., Okaji, K., 2005. Are increased nutrient inputs responsible for more outbreaks of crown-of-thorns starfish? An appraisal of the evidence. Mar. Pollut. Bull. 51 (1-4), 266-278.

Brodie, J.E., Kroon, F., Schaffelke, B., Wolanski, E., Lewis, S., Devlin, M., Bohnet, I., Bainbridge, Z., Waterhouse, J., Davis, A., 2012. Terrestrial pollutant runoff to the Great Barrier Reef: an update of issues, priorities and management responses. Mar. Pollut. Bull. 65 (4), 81-100.

Brodie, J.E., Waterhouse, J., Schaffelke, B., Johnson, J., Kroon, F., Thorburn, P., Rolfe, J., Lewis, S., Warne, M., Fabricius, K., 2013. Reef Water Quality Scientific Consensus Statement 2013. Department of the Premier and Cabinet, Queensland Government, Brisbane.

Brodie, J.E., Lewis, S.E., Collier, C.J., Wooldridge, S., Bainbridge, Z.T., Waterhouse, J., Rasheed, M.A., Honchin, C., Holmes, G., Fabricius, K., 2017. Setting ecologically relevant targets for river pollutant loads to meet marine water quality requirements for the Great Barrier Reef, Australia: a preliminary methodology and analysis. Ocean Coast. Manag. 143, 136-147.

Bureau of Meteorology, GA, 2011. Environmental attributes database. Retrieved 15/03/ 2016 http://www.ga.gov.au.

Carroll, C., Waters, D., Vardy, S., Silburn, D.M., Attard, S., Thorburn, P.J., Davis, A.M., Halpin, N., Schmidt, M., Wilson, B., 2012. A paddock to reef monitoring and modelling framework for the Great Barrier Reef: paddock and catchment component. Mar. Pollut. Bull. 65 (4), 136-149.

Celik, T., 2009. Unsupervised change detection in satellite images using principal component analysis and k-means clustering. IEEE Geosci. Remote Sens. Lett. 6 (4), 772-776.

Chabanet, P., Ralambondrainy, H., Amanieu, M., Faure, G., Galzin, R., 1997. Relationships between coral reef substrata and fish. Coral Reefs 16 (2), 93-102.

Chang, H., 2008. Spatial analysis of water quality trends in the Han River basin, South Korea. Water Res. 42 (13), 3285-3304.

Chantigny, M.H., 2003. Dissolved and water-extractable organic matter in soils: a review on the influence of land use and management practices. Geoderma 113 (3), 357-380.

Connell, J.H., 1978. Diversity in tropical rain forests and coral reefs. Science 199 (4335), 1302-1310.

Davis, A.M., Pearson, R.G., Brodie, J.E., Butler, B., 2016. Review and conceptual models of agricultural impacts and water quality in waterways of the Great Barrier Reef catchment area. Mar. Freshw. Res.

Davis, A.M., Pearson, R.G., Brodie, J.E., Butler, B., 2017. Review and conceptual models of agricultural impacts and water quality in waterways of the Great Barrier Reef catchment area. Mar. Freshw. Res. 68 (1), 1-19.

Dawson, J., Bakewell, C., Billett, M., 2001. Is in-stream processing an important control on spatial changes in carbon fluxes in headwater catchments?. Sci. Total Environ. 265 (1), 153-167.

De Valck, J., Rolfe, J., 2018. Linking water quality impacts and benefits of ecosystem services in the Great Barrier Reef. Mar. Pollut. Bull. 130, 55-66. 
De'ath, G., Fabricius, K.E., Sweatman, H., Puotinen, M., 2012. The 27-year decline of coral cover on the Great Barrier Reef and its causes. Proc. Natl. Acad. Sci. 109 (44), 17995-17999.

Devantier, L., De'ath, G., Turak, E., Done, T., Fabricius, K., 2006. Species richness and community structure of reef-building corals on the nearshore Great Barrier Reef. Coral Reefs 25 (3), 329-340.

Ding, C., He, X., 2004. K-means clustering via principal component analysis. In: Paper Presented at the Proceedings of the Twenty-first International Conference on Machine Learning.

Ding, J., Jiang, Y., Liu, Q., Hou, Z., Liao, J., Fu, L., Peng, Q., 2016. Influences of the land use pattern on water quality in low-order streams of the Dongjiang River basin, China: a multi-scale analysis. Sci. Total Environ. 551, 205-216.

Donnelly, C., Strömqvist, J., Arheimer, B., 2011. Modelling climate change effects on nutrient discharges from the Baltic Sea catchment: processes and results. IAHS Publ. 348, $1-6$.

Donohue, I., Mcgarrigle, M.L., Mills, P., 2006. Linking catchment characteristics and water chemistry with the ecological status of Irish rivers. Water Res. 40 (1), 91-98.

Edwards, A., Withers, P., 2008. Transport and delivery of suspended solids, nitrogen and phosphorus from various sources to freshwaters in the UK. J. Hydrol. 350 (3), 144-153.

Elledge, A., Thornton, C., 2012. The Brigalow Catchment Study: nitrogen runoff generation rates from pasture legumes and changes since land development. In: Paper Presented at the Hydrology and Water Resources Symposium 2012.

Elledge, A., Thornton, C., 2017. Effect of changing land use from virgin brigalow (Acacia harpophylla) woodland to a crop or pasture system on sediment, nitrogen and phosphorus in runoff over 25 years in subtropical Australia. Agric. Ecosyst. Environ. 239, 119-131.

Fabricius, K., Okaji, K., De'ath, G., 2010. Three lines of evidence to link outbreaks of the crown-of-thorns seastar Acanthaster planci to the release of larval food limitation. Coral Reefs 29 (3), 593-605.

Fritz, S.C., Anderson, N., 2013. The relative influences of climate and catchment processes on Holocene lake development in glaciated regions. J. Paleolimnol. 49 (3), 349-362.

Furnas, M.M., 2003. Catchments and Corals: Terrestrial Runoff to the Great Barrier Reef.

Gardolinski, P.C., Worsfold, P.J., Mckelvie, I.D., 2004. Seawater induced release and transformation of organic and inorganic phosphorus from river sediments. Water Res. 38 (3), 688-692.

Ginsburg, R., Shinn, E., 1995. Preferential distribution of reefs in the Florida reef tract: the past is the key to the present. Oceanogr. Lit. Rev. 8 (42), 674.

Granger, S., Bol, R., Anthony, S., Owens, P., White, S., Haygarth, P., 2010. Towards a holistic classification of diffuse agricultural water pollution from intensively managed grasslands on heavy soils. Adv. Agron. 105, 83-115.

Harris, G.P., 2001. Biogeochemistry of nitrogen and phosphorus in Australian catchments, rivers and estuaries: effects of land use and flow regulation and comparisons with global patterns. Mar. Freshw. Res. 52 (1), 139-149.

Hartigan, J.A., Wong, M.A., 1979. Algorithm AS 136: a k-means clustering algorithm. J. R. Stat. Soc.: Ser. C: Appl. Stat. 28 (1), 100-108.

Haygarth, P.M., Jarvis, S.C., 2002. Agriculture, Hydrology, and Water Quality. CABI, Wallingford.

Haynes, D., 2001. Great Barrier Reef water Quality: Current Issues. Great Barrier Reef Marine Park Authority.

Hoegh-Guldberg, O., Mumby, P.J., Hooten, A.J., Steneck, R.S., Greenfield, P., Gomez, E., Harvell, C.D., Sale, P.F., Edwards, A.J., Caldeira, K., 2007. Coral reefs under rapid climate change and ocean acidification. Science 318 (5857), 1737-1742.

Howley, C., Shellberg, J., Stephan, K., Brooks, A., 2013. Normanby Catchment Water Quality Management Plan. Australian Rivers Institute, Griffith University.

Hrachowitz, M., Benettin, P., Van Breukelen, B.M., Fovet, O., Howden, N.J., Ruiz, L., Van Der Velde, Y., Wade, A.J., 2016. Transit times-the link between hydrology and water quality at the catchment scale. Wiley Interdiscip. Rev. Water 3 (5), 629-657.

Hunter, H.M., Walton, R.S., 2008. Land-use effects on fluxes of suspended sediment, nitrogen and phosphorus from a river catchment of the Great Barrier Reef, Australia. J. Hydrol. 356 (1), 131-146.

Hutchings, P., Haynes, D., Goudkamp, K., Mccook, L., 2005. Catchment to reef: water quality issues in the Great Barrier Reef Region - an overview of papers. Mar. Pollut. Bull. 51 (1), 3-8.

Kleinman, P.J., Sharpley, A.N., Veith, T.L., Maguire, R.O., Vadas, P.A., 2004. Evaluation of phosphorus transport in surface runoff from packed soil boxes. J. Environ. Qual. 33 (4), 1413-1423.

Kroon, F.J., Kuhnert, P.M., Henderson, B.L., Wilkinson, S.N., Kinsey-Henderson, A., Abbott, B., Brodie, J.E., Turner, R.D., 2012. River loads of suspended solids, nitrogen, phosphorus and herbicides delivered to the Great Barrier Reef lagoon. Mar. Pollut. Bull. 65 (4), 167-181.

Kroon, F.J., Thorburn, P., Schaffelke, B., Whitten, S., 2016. Towards protecting the Great Barrier Reef from land-based pollution. Glob. Chang. Biol. 22 (6), 1985-2002.

Kuhnert, P.M., Henderson, B.L., Lewis, S.E., Bainbridge, Z.T., Wilkinson, S.N., Brodie, J.E., 2012. Quantifying total suspended sediment export from the Burdekin River catchment using the loads regression estimator tool. Water Resour. Res. 48 (4).

Letterman, R.D., 1999. Water Quality and Treatment: A Handbook of Community Water Supplies. McGraw-Hill Professional.

Li, S., Gu, S., Tan, X., Zhang, Q., 2009. Water quality in the upper Han River basin, China: the impacts of land use/land cover in riparian buffer zone. J. Hazard. Mater. 165 (1), 317-324.

Li, S., Li, J., Zhang, Q., 2011. Water quality assessment in the rivers along the water conveyance system of the Middle Route of the South to North Water Transfer Project
(China) using multivariate statistical techniques and receptor modeling. J. Hazard. Mater. 195, 306-317.

Lintern, A., Webb, J., Ryu, D., Liu, S., Bende-Michl, U., Waters, D., Leahy, P., Wilson, P., Western, A., 2018. Key factors influencing differences in stream water quality across space. Wiley Interdiscip. Rev. Water 5 (1).

Liu, C.-W., Lin, K.-H., Kuo, Y.-M., 2003. Application of factor analysis in the assessment of groundwater quality in a blackfoot disease area in Taiwan. Sci. Total Environ. 313 (1), 77-89.

Liu, S., Ryu, D., Western, A.W., Webb, J.A., Lintern, A., Waters, D., Thomson, B., 2017. Modelling the impact of land use and catchment characteristics on stream water quality using a Bayesian hierarchical modelling approach in the Great Barrier Reef catch ments. In: Paper Presented at the 22nd International Congress on Modelling and Simulation (MODSIM), Hobart, Australia.

Lowrance, R., Altier, L.S., Newbold, J.D., Schnabel, R.R., Groffman, P.M., Denver, J.M., Correll, D.L., Gilliam, J.W., Robinson, J.L., Brinsfield, R.B., 1997. Water quality functions of riparian forest buffers in Chesapeake Bay watersheds. Environ. Manag. 21 (5), 687-712.

Lynam, T., Drewry, J., Higham, W., Mitchell, C., 2010. Adaptive modelling for adaptive water quality management in the Great Barrier Reef region, Australia. Environ. Model. Softw. 25 (11), 1291-1301.

Macqueen, J., 1967. Some methods for classification and analysis of multivariate observations. In: Paper Presented at the Proceedings of the Fifth Berkeley Symposium on Mathematical Statistics and Probability.

Matlab and Statistics Toolbox. (2017). The MathWorks, Inc., Natick, Massachusetts, United States.

Mattsson, T., Kortelainen, P., Räike, A., 2005. Export of DOM from boreal catchments: impacts of land use cover and climate. Biogeochemistry 76 (2), 373-394.

Mccloskey, G., Ellis, R., Waters, D., Stewart, J., 2011. PEST hydrology calibration process for source catchments-applied to the Great Barrier Reef, Queensland. In: Paper Presented at the 19th International Congress on Modeling and Simulation, Perth, Australia.

Mckergow, L.A., Prosser, I.P., Hughes, A.O., Brodie, J., 2005. Sources of sediment to the Great Barrier Reef world heritage area. Mar. Pollut. Bull. 51 (1), 200-211.

Melching, C.S., Flores, H.E., 1999. Reaeration equations derived from US Geological Survey database. J. Environ. Eng. 125 (5), 407-414.

Mitchell, C., Brodie, J., White, I., 2005. Sediments, nutrients and pesticide residues in event flow conditions in streams of the Mackay Whitsunday Region, Australia. Mar. Pollut. Bull. 51 (1-4), 23-36.

Mitra, S., Ghosh, S., Satpathy, K.K., Bhattacharya, B.D., Sarkar, S.K., Mishra, P., Raja, P., 2017. Water quality assessment of the ecologically stressed Hooghly River Estuary, India: a multivariate approach. Mar. Pollut. Bull.

Moore, R., Richards, G., Story, A., 2008. Electrical conductivity as an indicator of water chemistry and hydrologic process. In: Streamline Watershed Management Bulletin. 11(2), pp. 25-29.

Mulholland, P.J., Hill, W.R., 1997. Seasonal patterns in streamwater nutrient and dissolved organic carbon concentrations: separating catchment flow path and in-stream effects. Water Resour. Res. 33 (6), 1297-1306.

Ng, A.Y., Jordan, M.I., Weiss, Y., 2002. On spectral clustering: analysis and an algorithm. In: Paper Presented at the Advances in Neural Information Processing Systems.

Ouyang, W., Song, K., Wang, X., Hao, F., 2014. Non-point source pollution dynamics under long-term agricultural development and relationship with landscape dynamics. Ecol. Indic. 45, 579-589.

Packett, R., Dougall, C., Rohde, K., Noble, R., 2009. Agricultural lands are hot-spots for annual runoff polluting the southern Great Barrier Reef lagoon. Mar. Pollut. Bull. 58 (7), 976-986

Palviainen, M., Laurén, A., Launiainen, S., Piirainen, S., 2016. Predicting the export and concentrations of organic carbon, nitrogen and phosphorus in boreal lakes by catchment characteristics and land use: a practical approach. Ambio 45 (8), 933-945.

Parinet, B., Lhote, A., Legube, B., 2004. Principal component analysis: an appropriate tool for water quality evaluation and management-application to a tropical lake system. Ecol. Model. 178 (3), 295-311

Peel, M.C., Finlayson, B.L., Mcmahon, T.A., 2007. Updated world map of the Köppen-Geiger climate classification. Hydrol. Earth Syst. Sci. Discuss. 4 (2), 439-473.

Petersen, W., Bertino, L., Callies, U., Zorita, E., 2001. Process identification by principal component analysis of river water-quality data. Ecol. Model. 138 (1), 193-213.

Petheram, C., Mcmahon, T.A., Peel, M.C., 2008. Flow characteristics of rivers in northern Australia: implications for development. J. Hydrol. 357 (1), 93-111.

Pratt, B., Chang, H., 2012. Effects of land cover, topography, and built structure on seasonal water quality at multiple spatial scales. J. Hazard. Mater. 209, 48-58.

Queensland Government, 2017. Mapping Erodible Soils in Burdekin Dry Tropics Grazing Lands Series.

Reddy, K., Patrick, W., Lindau, C., 1989. Nitrification-denitrification at the plant root-sediment interface in wetlands. Limnol. Oceanogr. 34 (6), 1004-1013.

Renard, K.G., Foster, G.R., Weesies, G., Mccool, D., Yoder, D., 1997. Predicting Soil Erosion by Water: A Guide to Conservation Planning With the Revised Universal Soil Loss Equation (RUSLE). vol. 703, US Government Printing Office, Washington, DC.

Rice, J.S., Emanuel, R.E., Vose, J.M., Nelson, S.A., 2015. Continental US streamflow trends from 1940 to 2009 and their relationships with watershed spatial characteristics. Water Resour. Res. 51 (8), 6262-6275.

Robson, B.J., 2014. State of the art in modelling of phosphorus in aquatic systems: review, criticisms and commentary. Environ. Model. Softw. 61, 339-359.

Rothwell, J., Dise, N., Taylor, K., Allott, T., Scholefield, P., Davies, H., Neal, C., 2010. Predicting river water quality across North West England using catchment characteristics. J. Hydrol. 395 (3), 153-162. 
Sangani, M.H., Amiri, B.J., Shabani, A.A., Sakieh, Y., Ashrafi, S., 2015. Modeling relationships between catchment attributes and river water quality in southern catchments of the Caspian Sea. Environ. Sci. Pollut. Res. 22 (7), 4985-5002.

Santhi, C., Srinivasan, R., Arnold, J.G., Williams, J., 2006. A modeling approach to evaluate the impacts of water quality management plans implemented in a watershed in Texas. Environ. Model. Softw. 21 (8), 1141-1157.

Schwarzenbach, R.P., Egli, T., Hofstetter, T.B., Von Gunten, U., Wehrli, B., 2010. Global water pollution and human health. Annu. Rev. Environ. Resour. 35, 109-136.

Shrestha, S., Kazama, F., 2007. Assessment of surface water quality using multivariate statistical techniques: a case study of the Fuji river basin, Japan. Environ. Model. Softw. 22 (4), 464-475.

Sidle, R.C., Tani, M., Ziegler, A.D., 2006. Catchment processes in Southeast Asia: atmospheric, hydrologic, erosion, nutrient cycling, and management effects. For. Ecol. Manag. 224 (1), 1-4.

Singh, K.P., Malik, A., Mohan, D., Sinha, S., 2004. Multivariate statistical techniques for the evaluation of spatial and temporal variations in water quality of Gomti River (India)—a case study. Water Res. 38 (18), 3980-3992.

Smith, R.A., Schwarz, G.E., Alexander, R.B., 1997. Regional interpretation of water-quality monitoring data. Water Resour. Res. 33 (12), 2781-2798.

Spearman, C., 2010. The proof and measurement of association between two things. Int. J. Epidemiol. 39 (5), 1137-1150.

Stephen Lewis, J.B., Andersen, Jenny, Armour, John, Baillie, Craig, Davis, Aaron, Eaglesham, Geoff, Amanda, E. Elledge, EF, Flores, Florita, Gallen, Christie, Kookana, Rai, McHugh, Jack, Bronwyn Masters, Phil, Mercurio, C.M., Mueller, Jochen, Negri, Andrew P., O'Brien, Dominique, Oliver, Danni, Bob, Packett, CP, Rojas-Ponce, Samuel, Shaw, Melanie, Silburn, David Mark, Smith, Rachael, Craig, M., Thornton, R.T., Warne, Michael, 2014. Pesticide Dynamics in the Great Barrier Reef Catchment and Lagoon: Management Practices (Sugar, Grazing, Bananas) and Risk Assessments: Overview Report for Project Number RRRD037 and RRRD038, (Retrieved from Cairns).

Suif, Z., Amr, F., Yoshimura, C., Saavedra, O., 2016. Spatio-temporal patterns of soil erosion and suspended sediment dynamics in the Mekong River Basin. Sci. Total Environ.

Terrestrial Ecosystem Research Network, 2016. Soil and landscape grid of Australia [WWW document]. Retrieved from http://www.clw.csiro.au/aclep/ soilandlandscapegrid/index.html.

Thorburn, P., Wilkinson, S., Silburn, D., 2013. Water quality in agricultural lands draining to the Great Barrier Reef: a review of causes, management and priorities. Agric. Ecosyst. Environ. 180, 4-20.

Turner, R., Huggins, R., Wallace, R., Smith, R., Vardy, S., Warne, M.S.J., 2012. Sediment, Nutrient and Pesticide Loads: Great Barrier Reef Catchment Loads Monitoring 2009-2010. Department of Science. Information Technology, Innovation and the Arts, Brisbane, 53.

Uriarte, M., Yackulic, C.B., Lim, Y., Arce-Nazario, J.A., 2011. Influence of land use on water quality in a tropical landscape: a multi-scale analysis. Landsc. Ecol. 26 (8), 1151.
Vadas, P., Kleinman, P., Sharpley, A., Turner, B., 2005. Relating soil phosphorus to dissolved phosphorus in runoff. J. Environ. Qual. 34 (2), 572-580.

Vrebos, D., Beauchard, O., Meire, P., 2017. The impact of land use and spatial mediated processes on the water quality in a river system. Sci. Total Environ. 601, 365-373.

Wallace, R., Huggins, R., King, O., Gardiner, R., Thomson, B., Orr, D., Ferguson, B., Taylor, C., Severino, Z., Smith, R., 2016. Total Suspended Solids, Nutrient and Pesticide Loads (2014-2015) for Rivers That Discharge to the Great Barrier Reef-Great Barrier Reef Catchment Loads Monitoring Program. Department of Science. Information Technology and Innovation, Brisbane, 3.

Wang, Q., Shrestha, D.L., Robertson, D., Pokhrel, P., 2012. A log-sinh transformation for data normalization and variance stabilization. Water Resour. Res. 48 (5).

Waters, D., Carroll, C., Ellis, R., Hateley, L., Mccloskey, J., Packett, R., Dougall, C., Fentie, B., 2013. Modelling Reductions of Pollutant Loads Due to Improved Management Practices in the Great Barrier Reef Catchments-Whole of GBR. vol. 1, Department of Natural Resources and Mines, (Retrieved from).

Waters, D., Carroll, C., Ellis, R., Hateley, L., Mccloskey, G., Packett, R., Dougall, C., Fentie, B., 2014. Technical Report Modelling Reductions of Pollutant Loads Due to Improved Management Practices in the Great Barrier Reef Catchments-Whole of GBR. vol. 1, Queensland Department of Natural Resources and Mines, Toowoomba, Queensland.

Westfall, P.H., 2014. Kurtosis as peakedness, 1905-2014. RIP. Am. Stat. 68 (3), 191-195.

Wooldridge, S.A., Done, T.J., 2009. Improved water quality can ameliorate effects of climate change on corals. Ecol. Appl. 19 (6), 1492-1499.

Wu, J., Stewart, T.W., Thompson, J.R., Kolka, R.K., Franz, K.J., 2015. Watershed features and stream water quality: gaining insight through path analysis in a Midwest urban landscape, USA. Landsc. Urban Plan. 143, 219-229.

Yang, Y.-H., Zhou, F., Guo, H.-C., Sheng, H., Liu, H., Dao, X., He, C.-J., 2010. Analysis of spatial and temporal water pollution patterns in Lake Dianchi using multivariate statistical methods. Environ. Monit. Assess. 170 (1-4), 407-416.

Zha, H., He, X., Ding, C., Gu, M., Simon, H.D., 2002. Spectral relaxation for k-means clustering. In: Paper Presented at the Advances in Neural Information Processing Systems.

Zhang, Q., Li, Z., Zeng, G., Li, J., Fang, Y., Yuan, Q., Wang, Y., Ye, F., 2009. Assessment of surface water quality using multivariate statistical techniques in red soil hilly region: a case study of Xiangjiang watershed, China. Environ. Monit. Assess. 152 (1-4), 123-131.

Zhou, F., Guo, H., Liu, Y., Jiang, Y., 2007. Chemometrics data analysis of marine water quality and source identification in Southern Hong Kong. Mar. Pollut. Bull. 54 (6), 745-756.

Zhou, F., Liu, Y., Guo, H., 2007. Application of multivariate statistical methods to water quality assessment of the watercourses in Northwestern New Territories, Hong Kong. Environ. Monit. Assess. 132 (1-3), , 1-13.

Zia, H., Harris, N.R., Merrett, G.V., Rivers, M., Coles, N., 2013. The impact of agricultural activities on water quality: a case for collaborative catchment-scale management using integrated wireless sensor networks. Comput. Electron. Agric. 96, 126-138. 